\title{
Flooding in the South Platte River and Fountain Creek Basins in Eastern Colorado, September 9-18, 2013
}

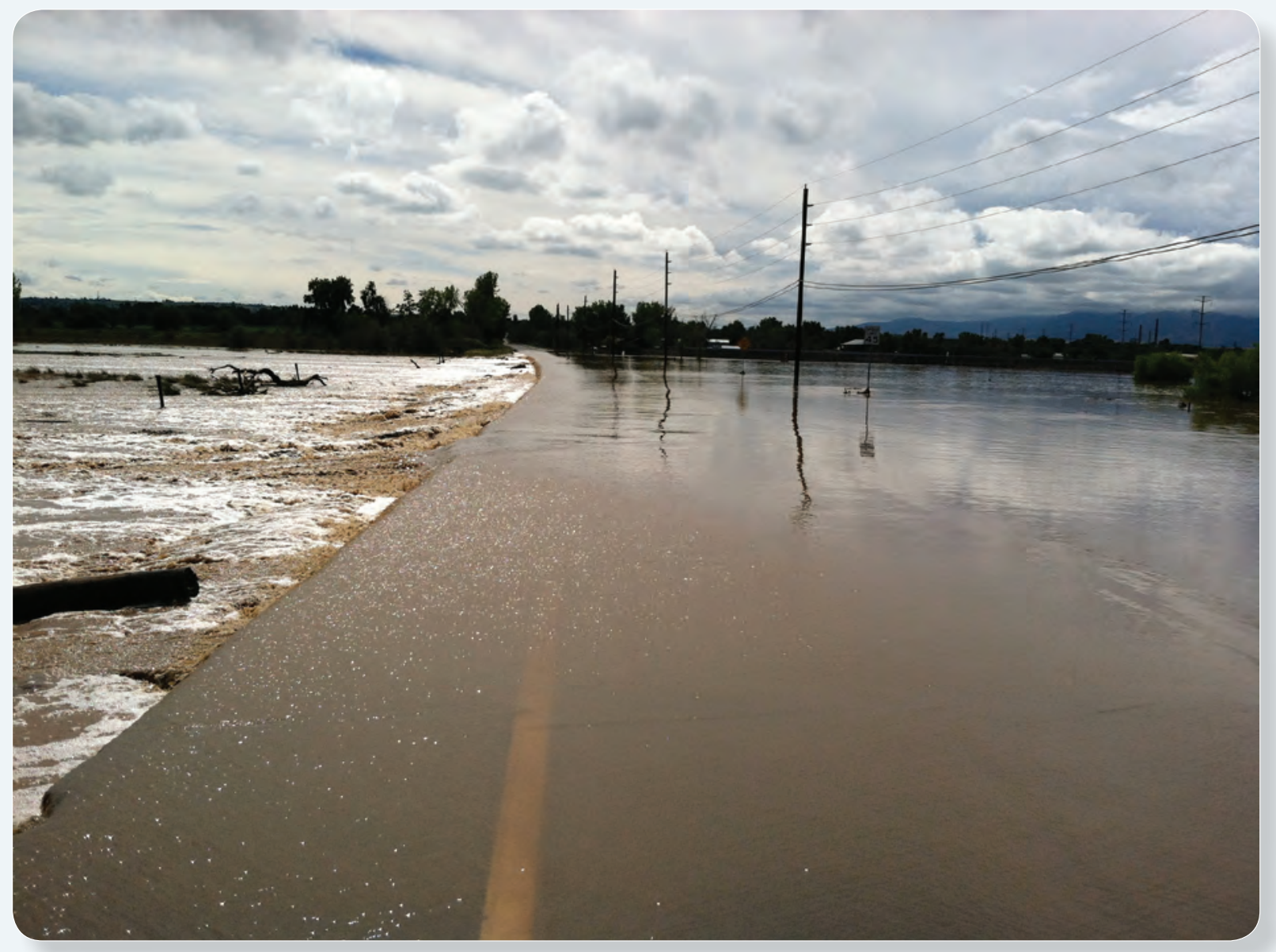

Scientific Investigations Report 2015-5119 
Cover. Flooding from Boulder Creek, looking south on North 75th Street near Boulder, Colorado, September 13, 2013. Photograph by Kit Fuller, U.S. Geological Survey. 


\section{Flooding in the South Platte River and Fountain Creek Basins in Eastern Colorado, September 9-18, 2013}

By Robert A. Kimbrough and Robert R. Holmes, Jr.

Scientific Investigations Report 2015-5119 


\title{
U.S. Department of the Interior SALLY JEWELL, Secretary
}

\section{U.S. Geological Survey Suzette M. Kimball, Acting Director}

\author{
U.S. Geological Survey, Reston, Virginia: 2015
}

For more information on the USGS - the Federal source for science about the Earth, its natural and living resources, natural hazards, and the environment—visit http://www.usgs.gov or call 1-888-ASK-USGS.

For an overview of USGS information products, including maps, imagery, and publications, visit http://www.usgs.gov/pubprod/.

Any use of trade, firm, or product names is for descriptive purposes only and does not imply endorsement by the U.S. Government.

Although this information product, for the most part, is in the public domain, it also may contain copyrighted materials as noted in the text. Permission to reproduce copyrighted items must be secured from the copyright owner.

Suggested citation:

Kimbrough, R.A., and Holmes, R.R., Jr., 2015, Flooding in the South Platte River and Fountain Creek Basins in eastern Colorado, September 9-18, 2013: U.S. Geological Survey Scientific Investigations Report 2015-5119, 33 p., http://dx.doi.org/10.3133/sir20155119.

ISSN 2328-0328 (online) 


\section{Acknowledgments}

This study could not have been accomplished without the assistance from numerous staff from the U.S. Geological Survey (USGS) who spent many hours in the field during the September 2013 flood ensuring that streamgages were recording accurate data, and post flood collecting data that ultimately were used to calculate peak streamflows for the event. In particular, the authors acknowledge the dedicated efforts from staff in the Lakewood and Southeast Colorado Field Offices of the USGS Colorado Water Science Center, and to the USGS employees who traveled to Colorado from out of State shortly after the event to assist with field work. In addition, the authors acknowledge the valuable assistance from the Colorado Division of Water Resources and Urban Drainage and Flood Control District for making hydrologic data from September 2013 available for inclusion in this report. Finally, the authors acknowledge the Office of Surface Water of the USGS Water Mission Area for partially funding this study. The authors thank John Fulton, Richard Kiah, Zachary Martin, Rodger Ortiz, Michael Roark, and Betty Palcsak for their thoughtful reviews of the document. A thank you also goes to the Rolla Publishing Servicing Center of the USGS for graphic design and report publication. 


\section{Contents}

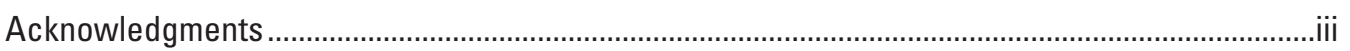

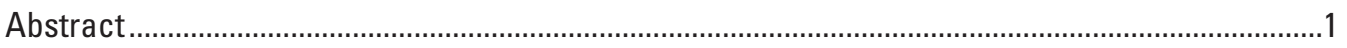

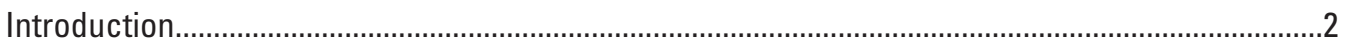

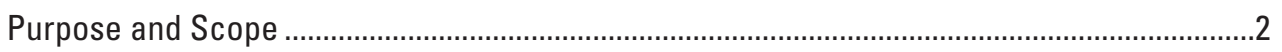

Description of the South Platte River and Fountain Creek Basins .............................................2

Flooding Dynamics and Select Historic Floods .................................................................

General Weather Conditions Leading to the Flooding .................................................................

Data Collection Effort: Stream Stage, Streamflow, and Rainfall....................................................

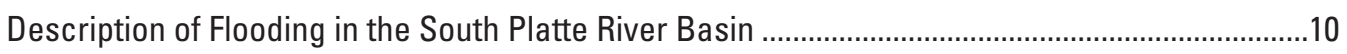

Plains Streams - Upstream from Denver to Fort Lupton.....................................................12

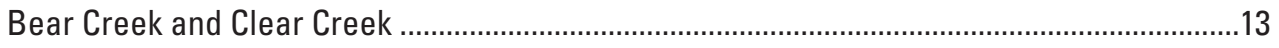

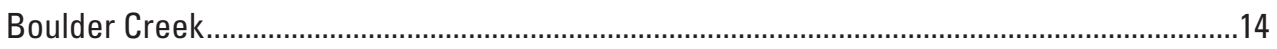

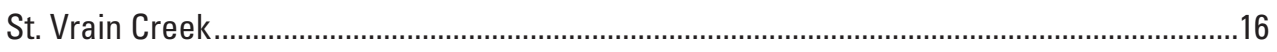

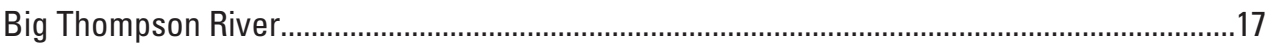

Cache la Poudre River .....................................................................................................

South Platte River — Near Greeley to Mouth .....................................................................18

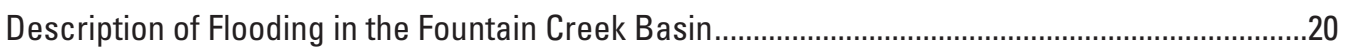

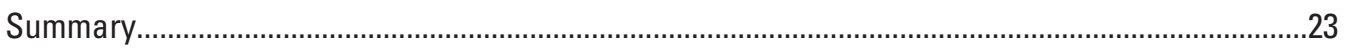

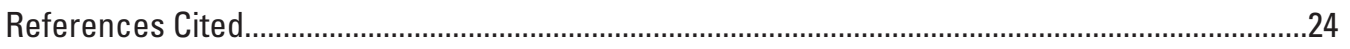

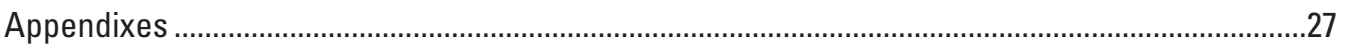

1-1. Peak stage and streamflow data at selected streamgages and non-gaged sites in the South Platte River and Fountain Creek Basins, September, 2013...............................28

1-2. Rainfall data for selected sites in the South Platte River and Fountain Creek Basins,

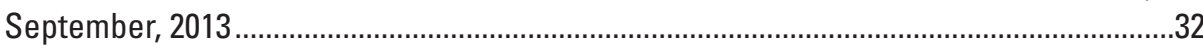

\section{Figures}

1. Map showing selected streamgages in the South Platte River and Fountain Creek Basins, eastern Colorado

2. Map showing sites in and along the Front Range of the Southern Rocky Mountains in the South Platte River Basin, eastern Colorado

3. Map showing sites in the upper Fountain Creek Basin, eastern Colorado .......................5

4. Photograph showing flood damage at the confluence of Little James and James Creeks in Jamestown, Colorado, located in the foothills northwest of Boulder, September 14, 2013.

5. Photograph showing overbank flooding along the South Platte River at U.S. Route 34 near Greeley, Colorado, on September 16, 2013

6. Map showing rainfall analysis for a part of the South Platte River Basin, eastern Colorado, during September 9-16, 2013.

7. Map showing annual exceedance probabilities for maximum 24-hour rainfall, September 9-16, 2013, for parts of the South Platte River Basin, eastern Colorado ........9

8. Photograph showing a U.S. Geological Survey field crew surveys high-water marks and channel geometry as part of an indirect measurement of streamflow 
9. Graph showing streamflow for Sand Creek above Burlington Ditch near Commerce City (site 24), and cumulative rainfall for Toll Gate at 6th Avenue at Aurora (site 23),

September 10-16, 2013, eastern Colorado

10. Graph showing streamflow for Bear Creek above Evergreen (site 8) and Clear Creek at Golden (site 28), September 9-16, 2013, and cumulative rainfall for Lookout Mountain Colorado (site 27), September 9-15, 2013, eastern Colorado

11. Graph showing stage for Boulder Creek Broadway (site 43), South Boulder Creek near Eldorado Springs (site 44), Coal Creek near Plainview (site 47), and Boulder Creek at North 75th Street near Boulder (site 46), and cumulative rainfall since September 9 at Sugar Loaf Colorado (site 40), September 11-14, 2013

12. Map showing extent of water surface on September 13,2013, at the confluence of the Boulder and St. Vrain Creeks, eastern Colorado, derived from remotely sensed data

13. Graphs showing stage for Middle St. Vrain at Peaceful Valley (site 34) and Big Thompson River below Moraine Park near Estes Park (site 51), and cumulative rainfall since September 9 at Johnny Park (site 35), September 10-14, 2013; and streamflow for St. Vrain Creek at Lyons (site 36), St. Vrain Creek at Longmont (site 37), St. Vrain Creek below Longmont (site 39), and St. Vrain Creek at mouth near Platteville (site 50), September 10-14, 2013

14. Graphs showing cumulative rainfall 11 miles northwest of Fort Collins (site 58), and streamflow for the Cache la Poudre River at Fort Collins (site 59), July 31-August 2, 1976; and cumulative rainfall since September 911.8 miles northwest of Fort Collins (site 57), and streamflow for the Cache la Poudre River at Fort Collins (site 59), September 11-14, 2013

15. Graphs showing peak streamflow in the South Platte River near Kersey (site 61) compared to peak streamflow in the South Platte River at Fort Morgan (site 64), 1935; South Platte River at Balzac (site 65), 1965; and South Platte River at Balzac (site 65), 1973

16. Graph showing stage, adjusted to a common base of 0 feet, for selected streamgages along the lower South Platte and Platte Rivers,

September 12-30, 2013

17. Map showing total rainfall at 32 locations in the Colorado Springs area, September 10-16, 2013

18. Graph showing cumulative rainfall for selected sites in the Colorado Springs area, September 10-16, 2013

19. Graph showing streamflow in Fountain Creek at Colorado Springs (site 99), Fountain Creek near Fountain (site 113), and cumulative rainfall since September 10 at the Rod and Gun meteorologic station at Fort Carson (site 112), September 12-13, 2013

\section{Tables}

1. Peak streamflow data that ranked in the top five for the period of record at selected streamgages with at least 10 years of record in the South Platte River Basin, September, 2013

2. Peak streamflow data that ranked in the top five for the period of record at selected streamgages with at least 10 years of record in the Fountain Creek Basin, September, 2013. 


\section{Conversion Factors}

Inch/Pound to International System of Units

\begin{tabular}{|c|c|c|}
\hline Multiply & By & To obtain \\
\hline \multicolumn{3}{|c|}{ Length } \\
\hline inch (in.) & 25.4 & millimeter (mm) \\
\hline foot $(\mathrm{ft})$ & 0.3048 & meter $(\mathrm{m})$ \\
\hline mile (mi) & 1.609 & kilometer (km) \\
\hline \multicolumn{3}{|c|}{ Area } \\
\hline square mile $\left(\mathrm{mi}^{2}\right)$ & 2.590 & square kilometer $\left(\mathrm{km}^{2}\right)$ \\
\hline \multicolumn{3}{|c|}{ Volume } \\
\hline cubic foot $\left(\mathrm{ft}^{3}\right)$ & 0.02832 & cubic meter $\left(\mathrm{m}^{3}\right)$ \\
\hline acre-foot (acre-ft) & 1,233 & cubic meter $\left(\mathrm{m}^{3}\right)$ \\
\hline \multicolumn{3}{|c|}{ Flow rate } \\
\hline cubic foot per second $\left(\mathrm{ft}^{3} / \mathrm{s}\right)$ & 0.02832 & cubic meter per second $\left(\mathrm{m}^{3} / \mathrm{s}\right)$ \\
\hline
\end{tabular}

\section{Datums}

Vertical coordinate information is referenced to the North American Vertical Datum of 1988 (NAVD 88).

Horizontal coordinate information is referenced to the North American Datum of 1983 (NAD 83).

Elevation, as used in this report, refers to distance above the vertical datum.

\section{Supplemental Information}

A water year is the 12-month period, 0ctober 1 through September 30, and is designated by the calendar year in which it ends. 


\title{
Flooding in the South Platte River and Fountain Creek Basins in Eastern Colorado, September 9-18, 2013
}

\author{
By Robert A. Kimbrough and Robert R. Holmes, Jr.
}

\section{Abstract}

On September 9, 2013, rain began to fall in eastern Colorado as a large low-pressure system pulled plumes of tropical moisture northward from the Pacific Ocean and the Gulf of Mexico. By September 16, 2013, as much as 12 to 20 inches of rain had fallen in the foothills of the Front Range of the Southern Rocky Mountains and adjacent plains near Colorado Springs, Colorado, north to the Colorado-Wyoming border. The rain caused major flooding during September 9-18, 2013, in a large part of the South Platte River Basin and in the Fountain Creek Basin. The floods resulted in several fatalities, more than 31,000 damaged or destroyed structures, and an estimated 3 billion dollars in damages. The U.S. Geological Survey (USGS) documented peak stage, streamflow, or both from the flood event for 80 sites located on selected rivers and streams in the South Platte River and Fountain Creek Basins and on the Platte River in Nebraska. The majority of flood-peak streamflows occurred on September 12 or 13, 2013, coinciding with the period of maximum rainfall. The flood resulted in new record peak streamflows at 17 streamgages having at least 10 years of record; 13 in the South Platte River Basin and 4 in the Fountain Creek Basin.

Flooding in the South Platte River Basin was primarily contained to select streams in Aurora and the Denver metropolitan area, most of the mountain tributaries joining the main stem South Platte River from Denver to Greeley, and in the main stem South Platte River from Denver to the ColoradoNebraska State line. In Aurora, where about 15 inches of rain fell, streamflow peaked at 5,470 cubic feet per second $\left(\mathrm{ft}^{3} / \mathrm{s}\right)$ in Toll Gate Creek, a tributary to Sand Creek. Downstream from Aurora near the confluence with the South Platte River, Sand Creek peaked at $14,900 \mathrm{ft}^{3} / \mathrm{s}$, which was the highest streamflow since at least 1992, but less than the peak of $25,500 \mathrm{ft}^{3} / \mathrm{s}$ in 1957 that occurred 4 miles upstream from the mouth. Flood-peak streamflows in the Denver metropolitan area were generally below historic records. The peak of $3,930 \mathrm{ft}^{3} / \mathrm{s}$ on September 12 at the State of Colorado streamgage South Platte River at Denver ranked 59 out of 116 peaks and was less than the 1965 peak of $40,300 \mathrm{ft}^{3} / \mathrm{s}$. Ten of the 13 streamgages in the South Platte River Basin with new record peak streamflows were located on the mountain tributaries; Bear Creek, Fourmile Creek, Boulder Creek, St. Vrain Creek, the Big Thompson River, and the Cache la Poudre River. A daily average streamflow of $8,910 \mathrm{ft}^{3} / \mathrm{s}$ on September 13 in Boulder Creek at the confluence with St. Vrain Creek was more than twice the previous instantaneous peak of $4,410 \mathrm{ft}^{3} / \mathrm{s}$ from 1938. The USGS calculated a peak streamflow of 23,800 $\mathrm{ft}^{3} / \mathrm{s}$ for the St. Vrain Creek at Lyons; the highest streamflow on record at this State of Colorado streamgage (122 years of record) is $10,500 \mathrm{ft}^{3} / \mathrm{s}$ from 1941. A peak streamflow of $16,200 \mathrm{ft}^{3} / \mathrm{s}$ was calculated for the Big Thompson River at mouth of canyon near Drake streamgage, which is the second highest peak in 90 years of record and about one-half the magnitude of the peak of $31,200 \mathrm{ft}^{3} / \mathrm{s}$ from July 31,1976 . A streamflow of $60,000 \mathrm{ft}^{3} / \mathrm{s}$ in the South Platte River at Fort Morgan (September 15, 2013) suggests that a new record streamflow occurred in the main stem in the Greeley area, about 45 miles upstream from Fort Morgan. The current peak of record at a State of Colorado streamgage at Kersey, about 6.5 miles downstream from Greeley, is $31,500 \mathrm{ft}^{3} / \mathrm{s}$ from 1973. Given that there was minimal inflow between Kersey and Fort Morgan, the USGS estimates there was probably at least $60,000 \mathrm{ft}^{3} / \mathrm{s}$ at Kersey, which would be almost double the peak streamflow of record from 1973.

Flooding in the Fountain Creek Basin was primarily contained to Fountain Creek from southern Colorado Springs to its confluence with the Arkansas River in Pueblo, in lower Monument Creek, and in several mountain tributaries. New record peak streamflows occurred at four mountain tributary streamgages having at least 10 years of record; Bear Creek, Cheyenne Creek, Rock Creek, and Little Fountain Creek. Five streamgages with at least 10 years of record in a 32-mile reach of Fountain Creek extending from Colorado Springs to Piñon had peak streamflows in the top five for the period of record. A peak of $15,300 \mathrm{ft}^{3} / \mathrm{s}$ at Fountain Creek near Fountain was the highest streamflow recorded in the Fountain Creek Basin during the September 2013 event and ranks the third highest peak in 46 years. Near the mouth of the basin, a peak of $11,800 \mathrm{ft}^{3} / \mathrm{s}$ in Pueblo was only the thirteenth highest annual peak in 74 years. A new Colorado record for daily rainfall of 11.85 inches was recorded at a USGS rain gage in the Little Fountain Creek Basin on September 12, 2013. 


\section{Introduction}

Excessive rainfall resulted in major flooding during September 9-18, 2013, in eastern Colorado including a large part of the South Platte River Basin, primarily north of and downstream from Denver, and in the Fountain Creek Basin, a tributary to the Arkansas River (fig. 1). During September 9-16, 2013, as much as 12 to 20 inches of rain fell in the foothills of the Front Range of the Southern Rocky Mountains and adjacent plains near Colorado Springs, Colorado, north to the Colorado-Wyoming border (National Oceanic and Atmospheric Administration, 2014a; U.S. Geological Survey, 2014). The floods resulted in 10 fatalities, more than 31,000 damaged or destroyed structures, and an estimated 3 billion dollars in damages (Colorado Division of Homeland Security and Emergency Management, 2014). On September 14, 2013, the Federal Emergency Management Agency (FEMA) issued a major disaster declaration that ultimately included 19 counties (Federal Emergency Management Agency, 2014).

The U.S. Geological Survey (USGS) documented the occurrence and magnitude of flooding at selected sites in the South Platte River and Fountain Creek Basins and on the Platte River in Nebraska. Most of the sites were at streamgages operated by the USGS or other agencies. In the South Platte River and Fountain Creek Basins, the USGS operates about 100 streamgages in cooperation with numerous local, State, and Federal agencies. The Colorado Division of Water Resources operates a network of streamgages in the South Platte River Basin, with some dating back to the 1880 s (Ley and others, 2010). The Urban Drainage and Flood Control District manages a network of streamgages in Denver and parts of six counties surrounding Denver (Urban Drainage and Flood Control District, 2014a). At locations where streamgage data were not available during the peak of flooding, field surveys of high-water marks were obtained to calculate peak streamflow. Several others have documented peak streamflow for this event using data from streamgages or the results of field surveys (Yochum and Moore, 2013; CH2MHILL, 2014; Colorado Division of Water Resources, 2014a; Griffin, 2014; Houck, 2014; Jacobs Engineering Group, Inc., 2014a, 2014b, 2014c; Urban Drainage and Flood Control District, 2014b, 2014c; URS, 2014).

\section{Purpose and Scope}

This report summarizes the results of a study to document flooding in the South Platte River and Fountain Creek Basins in eastern Colorado, September 9-18, 2013. Data collection and a synopsis of the general weather conditions that preceded the flooding are included. Peak stream stage, streamflow, or both, that transpired during the flood are presented for 80 sites (data for 72 of the 80 sites were determined by the USGS).
Flood-peak streamflow for 62 streamgages are placed into historical context by ranking the streamflows with the annual peak streamflows for the period of record at each streamgage. Graphs of continuous stage or streamflow for selected streamgages show the timing and magnitude of peak data during the flood event. Rainfall data collected during the event are presented for 5 sites in the South Platte River Basin and 32 sites in the Fountain Creek Basin. Graphs of cumulative rainfall, some of which accompany graphs of continuous stage or streamflow, are presented for selected sites. Annual Exceedance Probabilities for the September 2013 flood-peak streamflows are not included in this report. An analysis of the effects of urbanization and regulation on the flood-peak streamflows is recommended as part of any future flood-frequency analyses for these sites.

\section{Description of the South Platte River and Fountain Creek Basins}

The South Platte River and Fountain Creek Basins have headwater streams originating in the Front Range of the Southern Rocky Mountains (hereafter referred to as the "Front Range"). Mountain peaks greater than 14,000 feet ( $\mathrm{ft}$ ) in elevation are present in both basins. The headwater streams flow out of the Front Range foothills into the Great Plains Province at elevations ranging from about 5,500 to 7,000 ft. Most of the population of Colorado resides at the mountain/ plains interface from Pueblo to Fort Collins (fig. 1).

After exiting the mountains, the South Platte River flows north-northeast for about 80 miles (mi) to near Greeley, passing through the Denver metropolitan area and primarily agricultural land downstream from Denver. Between the metropolitan area and Greeley, several major mountain tributaries join the main stem South Platte River including Bear Creek, Clear Creek, St. Vrain Creek, the Big Thompson River, and the Cache la Poudre River (figs. 1 and 2). Between the mountains and the South Platte River, the mountain tributaries flow through mixed urban and agricultural land-use areas. From Greeley, the South Platte River flows east-northeast for about $230 \mathrm{mi}$ through the plains of eastern Colorado and western Nebraska before joining the North Platte River near North Platte, Nebraska (elevation about 2,800 ft). Plains streams (Crow Creek, Kiowa Creek, Bijou Creek, Beaver Creek, and Lodgepole Creek) are ephemeral and contribute little water to the South Platte River during most years (Dennehy and others, 1993). The South Platte River Basin has a drainage area of about 24,300 square miles $\left(\mathrm{mi}^{2}\right)$.

Exiting the foothills, Fountain Creek and Monument Creek flow southeast along the Front Range and are the two principal streams that form the Fountain Creek Basin (Kohn and others, 2014). Monument Creek flows through the Colorado Springs metropolitan area for about $7.5 \mathrm{mi}$ before joining 
Fountain Creek (fig. 3). Fountain Creek flows into Colorado Springs about $3 \mathrm{mi}$ upstream from the confluence with Monument Creek. Downstream from Monument Creek, Fountain Creek flows for about $44 \mathrm{mi}$ before joining the Arkansas River in Pueblo (elevation 4,640 ft) (fig. 1). Major tributaries in this lower reach include the mountain streams Bear Creek, Cheyenne Creek, Rock Creek, and Little Fountain Creek, and the plains streams Sand Creek and Jimmy Camp Creek (fig. 3).
Downstream from Sand Creek, Fountain Creek becomes wider and exhibits a more meandering and braided character than its upstream reaches (Zuellig and others, 2008). From Jimmy Camp Creek to Pueblo, Fountain Creek flows for about $26 \mathrm{mi}$ through relatively undeveloped land with the exception of a narrow band of some irrigated agriculture adjacent to the stream channel. The Fountain Creek Basin has a drainage area of $930 \mathrm{mi}^{2}$.

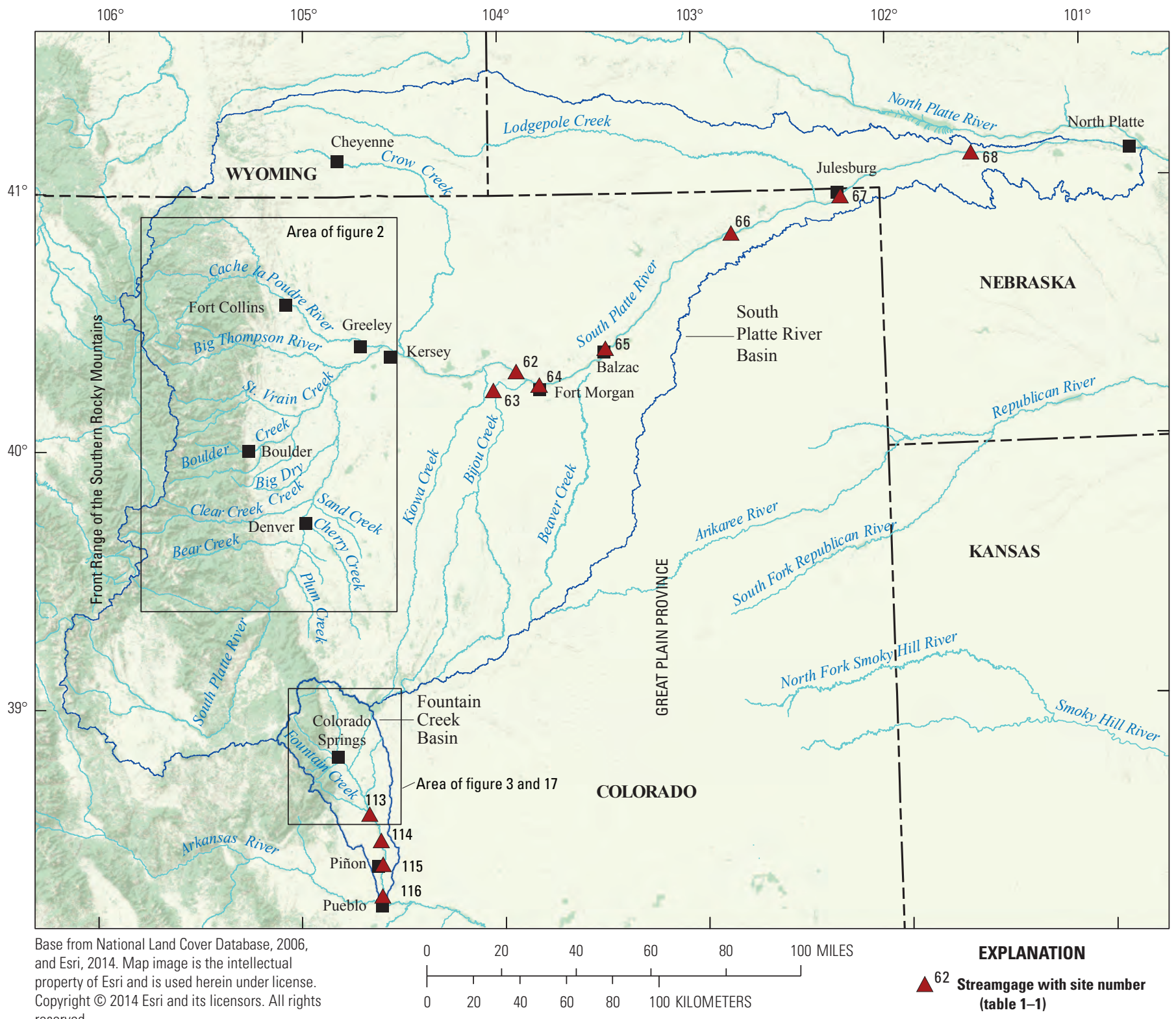

reserved.

Universal Transverse Mercator projection, zone 13

North American Datum of 1983

Figure 1. Selected streamgages in the South Platte River and Fountain Creek Basins, eastern Colorado. 


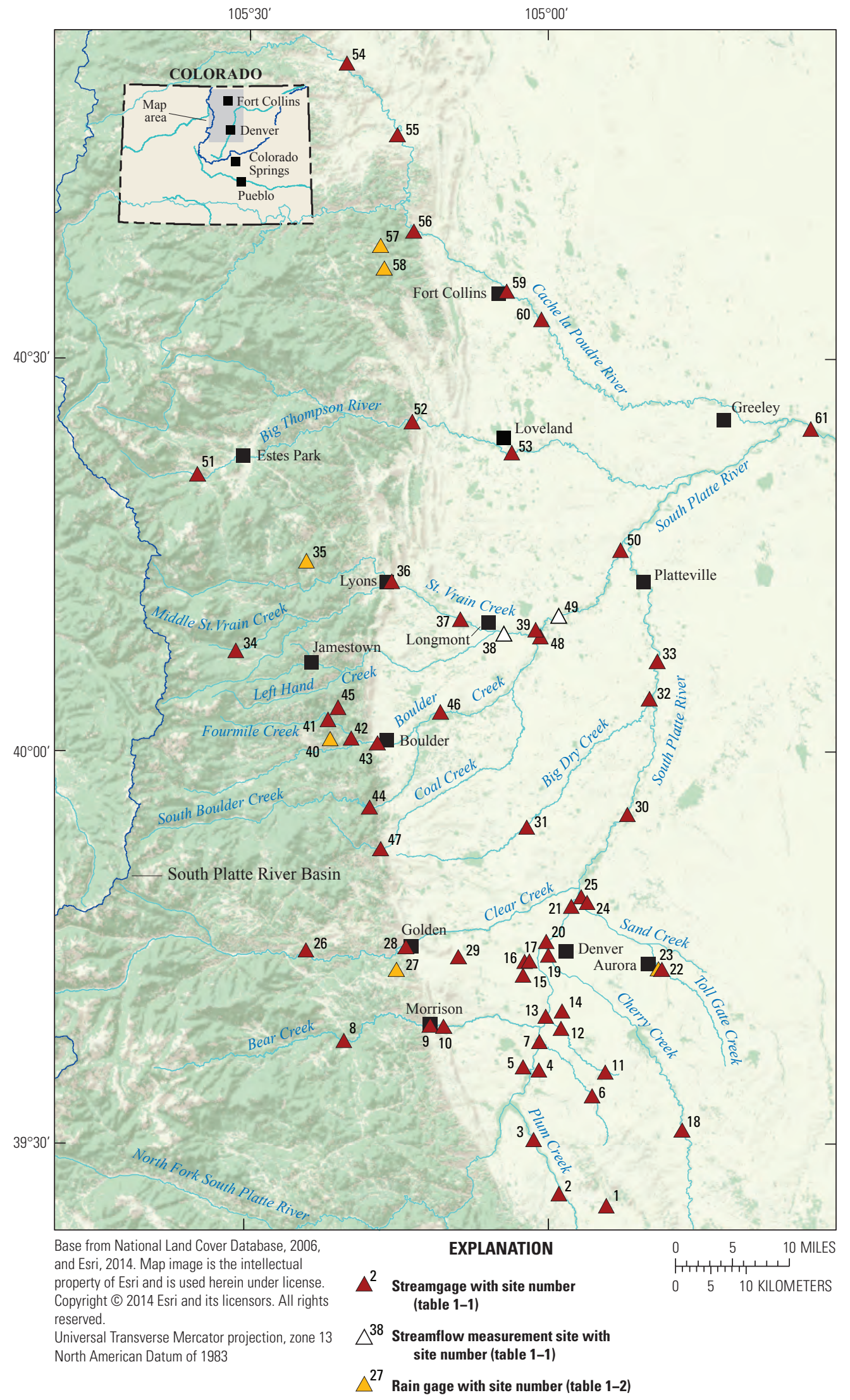

Figure 2. Sites in and along the Front Range of the Southern Rocky Mountains in the South Platte River Basin, eastern Colorado. 




Figure 3. Sites in the upper Fountain Creek Basin, eastern Colorado. 
Flooding in the South Platte River and Fountain Creek Basins in Eastern Colorado, September 9-18, 2013

\section{Flooding Dynamics and Select Historic Floods}

Flooding in the foothills of the Front Range and adjacent plains in eastern Colorado is primarily caused by rain, snowmelt, or a combination of rain falling on snow; however, snowmelt does not usually produce substantial flooding (McCain and Shroba, 1979). Rain events that produce flooding range from intense short-duration localized thunderstorms to large-scale multiday storms that can be accompanied by intense localized thunderstorms (Collins and others, 1991). Subtropical moisture from the Pacific Ocean and Gulf of Mexico transported into Colorado by mid-latitude frontal systems and monsoon circulation are major sources for rain in eastern Colorado (Collins and others, 1991). Easterly winds pushing humid air upward against the Front Range can exacerbate thunderstorm activity in and along the foothills, a process that contributed to the flood in the Big Thompson River in 1976 (Jarrett and Costa, 2006).

Flooding in foothills streams of the Front Range can be flashy because of the steep gradients and narrow channel valleys facilitating the rapid movement and concentration of surface runoff into the stream. The relatively large amount of water transported at high velocities typically results in extensive amounts of erosion and damage (fig. 4). No longer confined by steep canyon sidewalls, flood streamflows tend to produce overbank flooding after exiting the foothills into less steep topography. In September 2013, streamflow from mountain tributaries contributed to overbank flooding in the main stem of the South Platte River near Greeley (fig. 5).

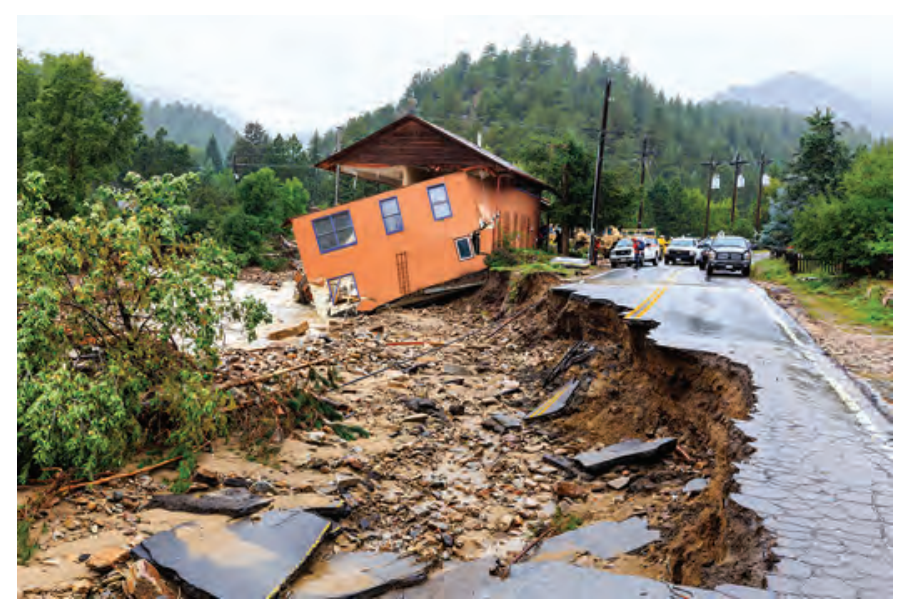

Figure 4. Flood damage at the confluence of Little James and James Creeks in Jamestown, Colorado, located in the foothills northwest of Boulder, September 14, 2013. Federal Emergency Management Agency News photograph.

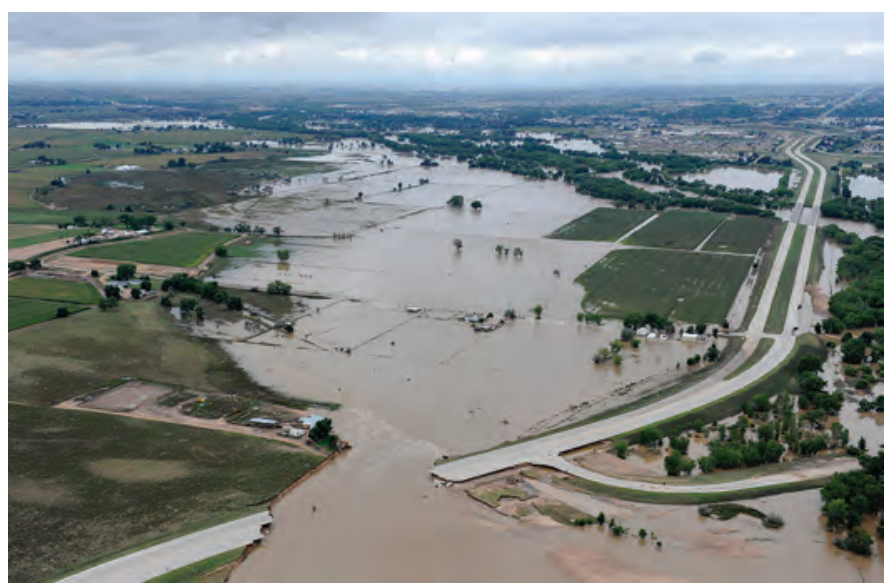

Figure 5. Overbank flooding along the South Platte River at U.S. Route 34 near Greeley, Colorado, on September 16, 2013. Photograph by the Denver Post.

Major floods in Colorado's Front Range and eastern plains during the last century include events in 1921, 1938, 1965, 1976, and 1997. In June 1921, widespread rains over several days combined with snowmelt to cause flooding in the South Platte River Basin extending from the foothills upstream from Denver to the Colorado-Nebraska State line. During this same storm, localized cloudbursts caused flash flooding on the Arkansas River and lower Fountain Creek that killed about 100 people in Pueblo (Follansbee and Sawyer, 1948). In September 1938, an atmospheric circulation pattern that persisted for 3 days transported subtropical moisture into eastern Colorado, resulting in flooding in nearly every Front Range stream from Colorado Springs to the Wyoming border (Lukas, 2013a). Rainfall over 5 days in June 1965 resulted in one of the largest floods in eastern Colorado in the 20th century, affecting most of the Arkansas River Basin east of the mountains and the plains region of the South Platte River Basin from just upstream from Denver to the Colorado-Nebraska State line (Matthai, 1969; Snipes and others, 1974). A peak streamflow of 40,300 cubic feet per second $\left(\mathrm{ft}^{3} / \mathrm{s}\right)$ at the South Platte River at Denver streamgage on June 17, 1965, remains the peak of record for that site. Other notable peak streamflows during the 1965 flood include a peak of $124,000 \mathrm{ft}^{3} / \mathrm{s}$ in Jimmy Camp Creek in the Fountain Creek Basin, and a peak of 466,000 ft $\mathrm{ft}^{3} / \mathrm{s}$ in Bijou Creek, a plains stream in the South Platte River Basin (Matthai, 1969; Snipes and others, 1974). Some of the more recent catastrophic localized flash floods generated by thunderstorms include the 1976 flood in the Big Thompson River canyon that killed 144 people and caused more than 35 million dollars in damages (Jarrett and Costa, 2006) and the 1997 Fort Collins flood that resulted in 5 deaths and caused an estimated 200 million dollars in damages (Colorado State University, 2007). 


\section{General Weather Conditions Leading to the Flooding}

Rain began to fall in parts of the South Platte River Basin on September 9, 2013, and in the Fountain Creek Basin on September 10 as a large slow-moving, upper-level, lowpressure system became nearly stationary over Nevada and Utah. The broad counterclockwise flow around this system pulled plumes of tropical moisture northward from the Pacific Ocean off the western coast of Mexico and the western Gulf of Mexico (National Oceanic and Atmospheric Administration, 2014a). By September 11, 2013, the combination of the low-pressure system, the presence of a stalled cold front across east-central Colorado, record amounts of precipitable water vapor in the atmosphere, and upslope easterly flow resulted in torrential rain in and along the Front Range of Colorado (National Oceanic and Atmospheric Administration, 2014a). Most of the rain fell in a 36-hour period, from the afternoon of September 11 until the early morning hours of September 13 (Lukas, 2013b).
Rainfall amounts in the South Platte River Basin for September 9-16, 2013, ranged from about 1 to 20 inches (fig. 6). Maximum rainfall in the South Platte River Basin was concentrated in the foothills in an area extending from west of Denver to north of Estes Park and in an area east of Denver that included the City of Aurora. As much as 12 inches of rain fell in the foothills west of Fort Collins and along the ColoradoWyoming border southwest of Cheyenne. During September 10-16, 2013, the National Weather Service Cooperative Observer rain gage in Boulder recorded new record rainfall amounts for 24 hours (9.08 inches), 48 hours (11.52 inches), and 7 days (16.9 inches) (Lukas, 2013b). This rain gage has records dating back to 1893 . Total rainfall at the Boulder rain gage for September 2013 totaled 18.16 inches, slightly less than the average annual amount of 18.99 inches (1893-2013) (National Oceanic and Atmospheric Administration, 2014b).

An analysis of the annual exceedance probability (AEP) for maximum 24-hour rainfall (worst cast 24-hour rainfall) provides a good indication of the rarity of this rainfall event. The AEP is the probability of exceeding a given amount of

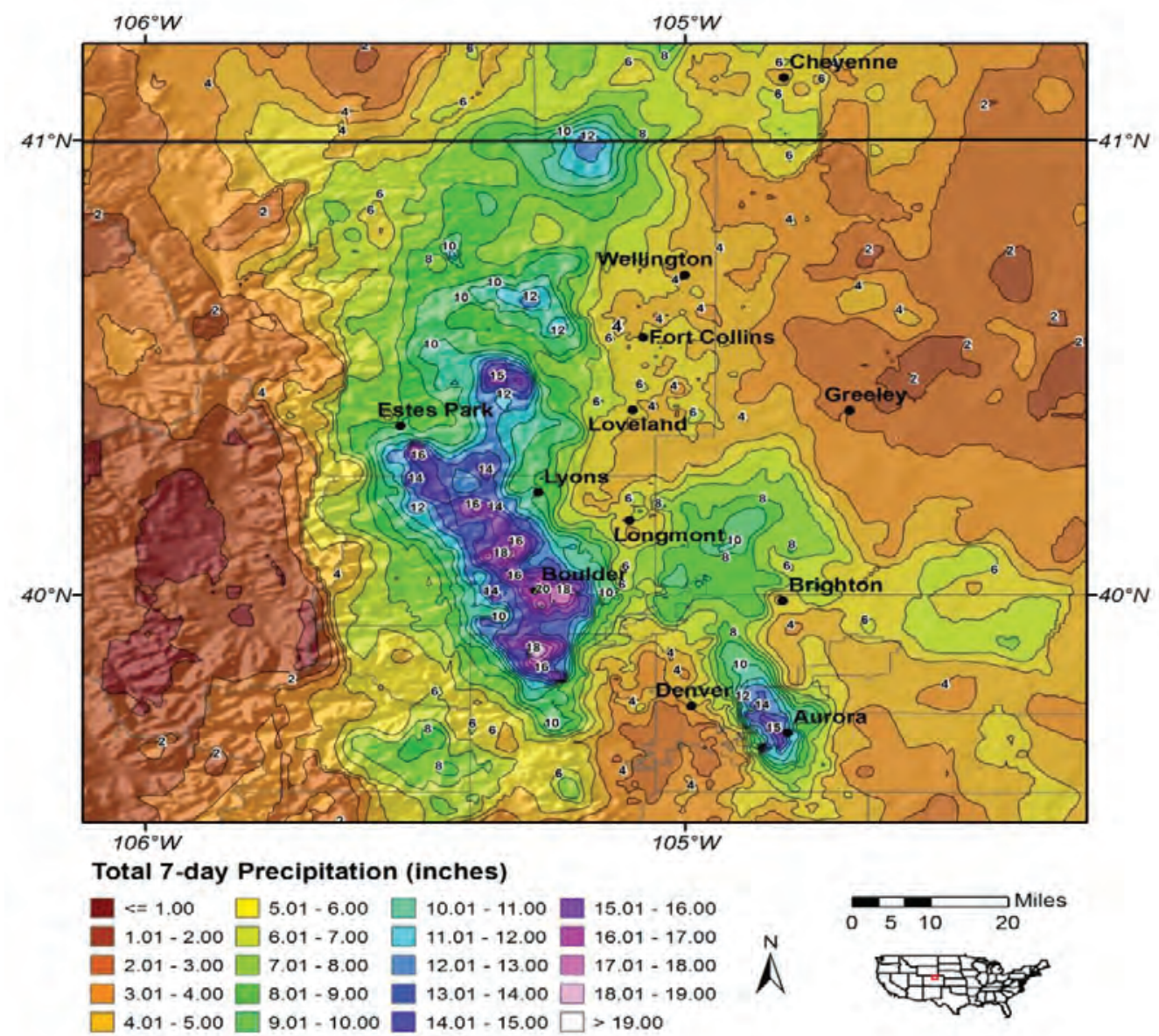

Map created with the Storm Precipitation Analysis System through a collaborative effort by Applied Weather Associates, LLC, MetStat, Inc., and the Colorado Climate Center, Colorado State University
National Oceanic and Atmospheric Administration, 2014; Radar data supplied by Weather Decision Technologies, Inc.

Figure 6. Rainfall analysis for a part of the South Platte River Basin, eastern Colorado, during September 9-16, 2013 (National Oceanic Atmospheric Administration, 2014a). 
rainfall at least once in any given year at a given location. A part of the South Platte River Basin that experienced maximum 24-hour rainfall magnitudes during September 9-16, 2013, with AEPs ranging from greater than 10 percent to less than 0.1 percent, is shown in figure 7 (National Oceanic and Atmospheric Administration, 2013). Swaths of AEPs ranging from less than 0.1 percent to about 0.2 percent were determined for areas extending northwest from Boulder to Estes Park and north from Aurora (fig. 7). The beginning and ending times of the maximum 24-hour rainfall observation period were not necessarily the same for each location. As a result, figure 7 does not represent isohyets of rainfall at any particular point in time.

In the Fountain Creek Basin, a network of rain gages operated by the USGS in the vicinity of Colorado Springs (fig. 3) measured between 2 and 16 inches of rain for September 10-16, 2013. Downstream from Colorado Springs, rainfall totals for September 10-16, 2013, were 2.17 inches in the City of Fountain, and 1.02 inches at the Pueblo Memorial Airport, 6 mi east of Pueblo (National Climatic Data Center, 2015a, 2015b). During September 10-16, 2013, 15.64 inches of rain were recorded at a USGS rain gage at Fort Carson, located just south of Colorado Springs in the Fountain Creek Basin (site 112, fig. 3). Of this amount, 11.85 inches fell from midnight on September 11 to midnight on September 12, setting a new daily-record rainfall amount for the State of Colorado (Nolan Doesken, State Climatologist for Colorado, written commun., 2014).

\section{Data Collection Effort: Stream Stage, Streamflow, and Rainfall}

Peak stream stage (water level), streamflow, or both, that transpired during the flood were collected for 80 sites (78 streamgages and 2 non-gaged sites) (table 1-1, figs. 1-3). Flood data for 72 of the sites were determined by the USGS (http://waterdata.usgs.gov/nwis), whereas data for 8 sites were obtained from other sources. Of the 80 sites, 54 are in the South Platte River Basin, 24 are in the Fountain Creek Basin, and 2 are on the Platte River in Nebraska (sites on the Platte River are not shown on figures; the Kearney, Nebr., site is about $100 \mathrm{mi}$ downstream from North Platte, and the Grand Island, Nebr., site is about 45 mi downstream from Kearney). Table 1-1 also includes 8 sites that are referenced in this report but peak stage and streamflow for September 2013 were not available. The streamgages and non-gaged sites included in table 1-1 were chosen because (1) the 2013 flood-peak streamflow for the streamgage ranked in the top five peak annual streamflows for the period of record, (2) the location was a non-gaged site where the peak streamflow was determined by indirect measurement, or (3) the streamgage was included to allow comparison of this event and past major floods. At 62 streamgages, the flood-peak streamflow was also the maximum annual peak streamflow for water year 2013 (a water year is the 12-month period, October 1 through September 30, and is designated by the calendar year in which it ends). For these streamgages, the flood-peak streamflow is placed into historical context by ranking the peak streamflow with the annual peak streamflows for the period of record (table 1-1).

Stream stage and streamflow data were collected either systematically at streamgages or derived from field observations obtained at streamgages or at locations where no streamgages were present (non-gaged sites). The typical streamgage automatically records observations of stream stage. Derivation of streamflow from stage data at a streamgage requires direct measurements of streamflow at various stages for constructing a relation that converts stage to streamflow. In most cases, the relation is a simple stagestreamflow rating curve. Onsite direct measurements of streamflow are calculated by USGS personnel using physical observations of stream velocity, depth, and width (Turnipseed and Sauer, 2010). Periodic measurements of streamflow are required to maintain calibration of the rating curve. The rating curve allows for the determination of streamflow from the stage data when USGS personnel are not physically present at the streamgage to make a streamflow measurement.

Alternatively, the USGS used indirect measurement methods to determine September 2013 flood-peak streamflows at 15 sites (non-gaged sites or at sites where streamgages did not provide adequate data during the flood) (table 1-1). Indirect measurements use water-surface profiles determined by high-water marks and channel geometry with hydraulic equations based on the principle of conservation of energy to compute peak streamflow (Benson and Dalrymple, 1967). The high-water marks and channel geometry are determined by field surveys (fig. 8). The methods used to estimate peak streamflow from the September 2013 flood at 14 of the 15 sites where indirect methods were employed include the contracted-opening method (Matthai, 1967), critical-depth method (Hulsing, 1967), culvert-computation method (Bodhaine, 1968), and the slope-area method (Dalrymple and Benson, 1968). The USGS assigns uncertainty estimates to each indirect measurement based on the hydraulic and geometry conditions present at each field site. Estimates of uncertainty for some of the indirect measurements conducted for the September 2013 flood event are included in this report.

The slope-area method was initially applied for computing peak streamflow in the St. Vrain Creek at Lyons (site 36). As part of this effort, the USGS surveyed more than 700 highwater marks and channel geometry at 8 cross sections in a $1 \mathrm{mi}$ reach of St. Vrain Creek in the town of Lyons (Chris Curran, U.S. Geological Survey, written commun., 2014). The value of peak streamflow computed from the slope-area method was ultimately discounted due to evidence that flow conditions in the St. Vrain Creek through the town of Lyons were highly non-uniform, precluding assumptions of onedimensional, uniform flow that are appropriate for the slopearea method (Mark Smith, U.S. Geological Survey, written commun., 2014). 


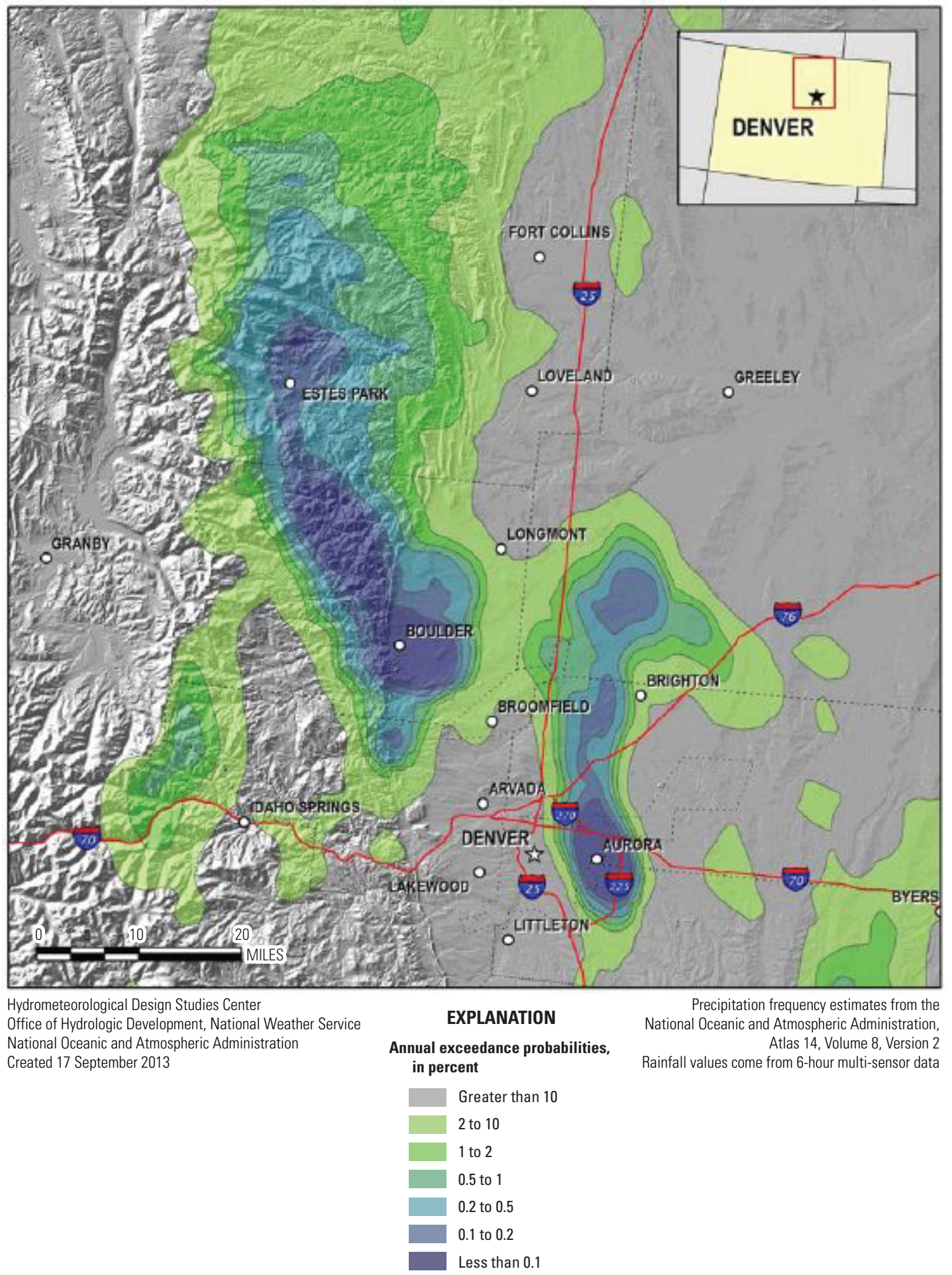

Figure 7. Annual exceedance probabilities (AEPs) for maximum 24-hour rainfall, September 9-16, 2013, for parts of the South Platte River Basin, eastern Colorado. Adapted from the National Oceanic Atmospheric Administration (2013). 


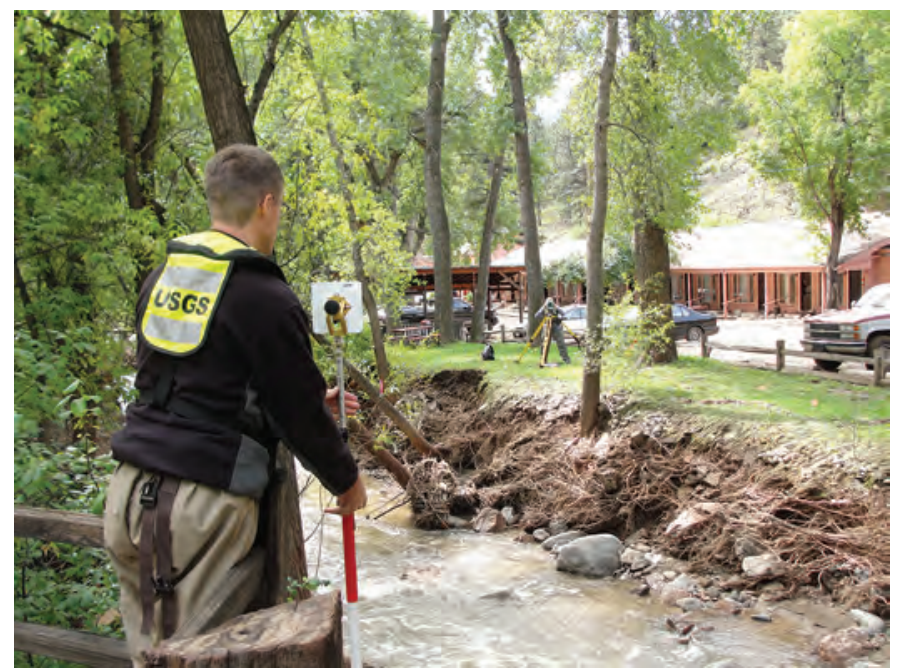

Figure 8. A U.S. Geological Survey field crew surveys high-water marks and channel geometry as part of an indirect measurement of streamflow.

As an alternative, peak streamflow at the St. Vrain Creek at Lyons (site 36), was determined using the USGS FaSTMECH (Flow and Sediment Transport with Morphological Evolution of Channels) two dimensional hydraulic model (Nelson and McDonald, 1996, Nelson and others, 2003, McDonald and others, 2006, Nelson and others, 2010). The model assumes flow is incompressible, hydrostatic, and quasi-steady, where quasi-steady indicates that the dynamic part of streamflow variations can be neglected in the equations expressing conservation of momentum (Nelson and others, 2010). A variety of topographic data were used for model calibration, including post-flood aerial light detection and ranging (lidar), and the surveys of channel geometry and high-water marks obtained for the slope-area computation.

To determine the optimal (peak) streamflow using FaSTMECH, the parameter space of both streamflow and surface roughness was modeled to find the best fit between the observed and simulated water-surface elevations. This involved modeling a range of streamflows using various scenarios of surface roughness where roughness was characterized by a drag coefficient. For each streamflow and surface-roughness simulation, the fit between the observed and simulated water-surface elevations was determined by calculating the root mean squared error. The optimal streamflow was identified by the combination of streamflow and surface roughness that produced the lowest root mean squared error, or the best fit to the observed water-surface elevation (inferred from the high-water marks) (Richard McDonald, U.S. Geological Survey, written commun., 2014).

Data from continuous-recording rain gages were used for calculating total cumulative rainfall for periods encompassing the September 2013 flood and for select sites, displaying rainfall intensity in graphs. Rainfall data were collected for 37 sites; 5 sites in the South Platte River Basin and 32 sites in the Fountain Creek Basin (table 1-2, figs. 2 and 3). Rainfall data for one site in the South Platte River Basin and all sites in the Fountain Creek Basin were collected using tipping bucket rain gages operated and maintained by the USGS using procedures similar to those documented by Gotvald (2010). Rainfall data for four sites in the South Platte River Basin were obtained from other sources (table 1-2).

Agencies other than the USGS collect streamflow data. For the most part, these data are collected using methods and standards similar to those used by the USGS. Any non-USGS data presented in this report have not been quality assured by USGS personnel; however, the collecting agency is identified. Any questions regarding methods of data collection for nonUSGS data should be referred to the collecting agency.

\section{Description of Flooding in the South Platte River Basin}

In September 2013, flooding in the South Platte River Basin in eastern Colorado was primarily contained to select streams in Aurora and the Denver metropolitan area, most of the mountain tributaries joining the main stem South Platte River from Denver to Greeley, and the main stem of the South Platte River from Denver to the Colorado-Nebraska State line. Large parts of the South Platte River Basin did not experience flooding in September 2013, including about 2,600 $\mathrm{mi}^{2}$ upstream from Denver, most of which is in the mountains. Downstream from Greeley, flooding in the main stem South Platte River resulted from the progression of the flood crest moving downstream and not from additional inflow from plains tributaries. The majority of flood peaks occurred on September 12 or 13, 2013, coinciding with the period of maximum rainfall (table 1-1). Streamgages on the lower South Platte River, including one in Nebraska, did not record peaks until September 15-21, 2013 (table 1-1). The flood crest in the South Platte River was recorded near the Colorado-Nebraska State line on September 18, 2013, at Julesburg, Colorado.

Twenty-nine streamgages in the South Platte River Basin with at least 10 years of record had peak streamflows during the September 2013 flood that ranked in the top five for the period of record, and 13 of those sites set a new record peak streamflow (table 1, table 1-1). The majority of streamgages with new record peak streamflow (10 of 13, table 1) were located on the mountain tributaries; Bear Creek, Fourmile Creek, Boulder Creek, St. Vrain Creek, the Big Thompson River, and the Cache la Poudre River. A new record peak streamflow at a streamgage does not necessarily mean that a higher streamflow has not been recorded on the same stream in the past. As an example, a record peak streamflow of $19,000 \mathrm{ft}^{3} / \mathrm{s}$ was calculated for the USGS streamgage on the Big Thompson River at Loveland (site 53) for the September 2013 event; however, the historic Big Thompson River flood of $1976 \mathrm{had}$ a peak streamflow of $31,200 \mathrm{ft}^{3} / \mathrm{s}$ at a site in the 
Table 1. Peak streamflow data that ranked in the top five for the period of record at selected streamgages with at least 10 years of record in the South Platte River Basin, September, 2013.

[no., number; USGS, U.S. Geological Survey; ft³/s, cubic feet per second; N. F., North Fork; Nebr., Nebraska]

\begin{tabular}{|c|c|c|c|c|c|}
\hline $\begin{array}{l}\text { Site no. } \\
\text { (fig. } 1 \text { or } 2 \text { ) }\end{array}$ & USGS site number & Site name & $\begin{array}{l}\text { Streamflow } \\
\left(f \mathrm{ft}^{3} / \mathbf{s}\right)\end{array}$ & Rank/ann & record \\
\hline 1 & 06708800 & East Plum Creek above Haskins Gulch near Castle Rock & 930 & 3 & 14 \\
\hline 2 & 06709000 & Plum Creek near Sedalia & 1,260 & 4 & 28 \\
\hline 6 & 06710150 & Big Dry Creek below C-470 at Highlands Ranch & 527 & 2 & 10 \\
\hline 8 & 06710385 & Bear Creek above Evergreen & 1,350 & 1 & 30 \\
\hline 10 & 06710605 & Bear Creek above Bear Creek Lake near Morrison & 1,800 & 1 & 28 \\
\hline 11 & 06711515 & Little Dry Creek near Arapahoe Road at Centennial & 631 & 3 & 28 \\
\hline 18 & 393109104464500 & Cherry Creek near Parker & 819 & 3 & 22 \\
\hline 25 & 394839104570300 & Sand Creek at mouth near Commerce City & 14,900 & 1 & 21 \\
\hline 26 & 06718550 & North Clear Creek above mouth near Black Hawk & 402 & 3 & 19 \\
\hline 29 & 06719560 & Lena Gulch at Lakewood & 546 & 4 & 33 \\
\hline 31 & 06720820 & Big Dry Creek at Westminster & 642 & 4 & 26 \\
\hline 32 & 06720990 & Big Dry Creek at mouth near Fort Lupton & 781 & 1 & 22 \\
\hline 33 & 06721000 & South Platte River at Fort Lupton & 10,300 & 1 & 40 \\
\hline 36 & 06724000 & St. Vrain Creek at Lyons ${ }^{a}$ & 23,800 & 1 & 122 \\
\hline 39 & 06725450 & St. Vrain Creek below Longmont & 31,700 & 1 & 35 \\
\hline 42 & 06727500 & Fourmile Creek at Orodell & 2,510 & 1 & 22 \\
\hline 46 & 06730200 & Boulder Creek at North 75th Street near Boulder & 8,400 & 1 & 27 \\
\hline 48 & 06730500 & Boulder Creek at mouth near Longmont ${ }^{b}$ & 8,910 & 1 & 62 \\
\hline 51 & 402114105350101 & $\begin{array}{l}\text { Big Thompson River below Moraine Park near } \\
\text { Estes Park }\end{array}$ & 1,130 & 1 & 15 \\
\hline 52 & 06738000 & Big Thompson River at mouth of canyon near Drake ${ }^{a}$ & 16,200 & 2 & 90 \\
\hline 53 & 06741510 & Big Thompson River at Loveland & 19,000 & 1 & 35 \\
\hline 54 & 06751150 & $\begin{array}{l}\text { N. F. Cache la Poudre River below Halligan Reservoir } \\
\text { near Virginia Dale }\end{array}$ & 1,050 & 2 & 15 \\
\hline 55 & 06751490 & N. F. Cache la Poudre River at Livermore & 4,510 & 2 & 27 \\
\hline 56 & 06752000 & $\begin{array}{l}\text { Cache la Poudre River at mouth of canyon near } \\
\text { Fort Collins }^{c}\end{array}$ & 9,730 & 4 & 131 \\
\hline 59 & 06752260 & Cache la Poudre River at Fort Collins & 8,140 & 1 & 39 \\
\hline 60 & 06752260 & $\begin{array}{l}\text { Cache la Poudre River above Box Elder Creek near } \\
\text { Timnath }\end{array}$ & 7,010 & 2 & 34 \\
\hline 64 & 06759500 & South Platte River at Fort Morgan & 60,000 & 2 & 28 \\
\hline 67 & 06764000 & South Platte River at Julesburg ${ }^{c}$ & 21,800 & 5 & 109 \\
\hline 68 & 06764880 & South Platte River at Roscoe, Nebr. & 19,100 & 2 & 31 \\
\hline
\end{tabular}

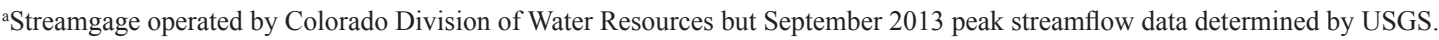

'Peak streamflow for September 2013 is an estimated daily average.

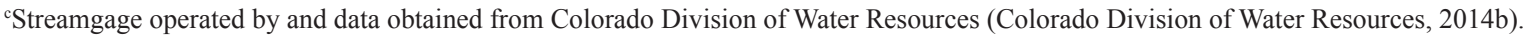


Big Thompson River Canyon, about 10 mi upstream from Loveland and 3 years prior to the establishment of the Big Thompson River at Loveland (site 53) streamgage.

\section{Plains Streams - Upstream from Denver to Fort Lupton}

Upstream from and south of Denver, more than 2 inches of rain in less than 2 hours on September 14 (Urban Drainage and Flood Control District, 2014a) resulted in floodpeak streamflows at sites in the Plum Creek Basin (sites 1, 2, and 3, table 1-1); however, the magnitude of the peaks was much less than the peak streamflow of $154,000 \mathrm{ft}^{3} / \mathrm{s}$ that transpired on Plum Creek in 1965 (Matthai, 1969). The rain on September 14 also extended east of Denver into Aurora and resulted in a peak streamflow of $5,470 \mathrm{ft}^{3} / \mathrm{s}$ on September 14 in Toll Gate Creek (site 22) a tributary to Sand Creek. Matthai (1969) reports peak streamflows in Toll Gate Creek of $16,000 \mathrm{ft}^{3} / \mathrm{s}$ in 1965 and $10,400 \mathrm{ft}^{3} / \mathrm{s}$ in 1957 . The rain on September 14 contributed to a total of about 15 inches of rain in Aurora for September 9-16, 2013 (fig. 6). A large part of Aurora is contained in the Sand Creek Basin, which joins the South Platte River in northeast Denver (figs. 1 and 2). Early on September 10, streamflow in Sand Creek 0.3 mi upstream from the confluence with the South Platte River (Sand Creek above Burlington Ditch near Commerce City, site 24) was about $2 \mathrm{ft}^{3} / \mathrm{s}$ (fig. 9). Site 24 recorded relatively small peaks in streamflow on September 10 and September 11-12 before quickly rising to a peak of $14,800 \mathrm{ft}^{3} / \mathrm{s}$ on September 12 that coincided with 5.8 inches of rain that fell in about 9 hours at the Toll Gate at 6th rain gage (site 23) located about $10.5 \mathrm{mi}$ upstream from the mouth of Sand Creek (fig. 2). A subsequent peak of $11,000 \mathrm{ft}^{3} / \mathrm{s}$ at site 24 on September 14 coincided with 2.2 inches of rain that fell in 1 hour at the Toll Gate at 6th rain gage ( site 23). Just downstream from site 24, peak streamflow on September 12 at Sand Creek at mouth near Commerce City (site 25) was $14,900 \mathrm{ft}^{3} / \mathrm{s}$. The peak streamflows on September 12 at sites 24 and 25 near the mouth of Sand Creek were the highest streamflows in Sand Creek since at least 1992. Peak streamflow data prior to 1992 is scarce; however, Matthai (1969) reports peak streamflow in Sand Creek at a location $4 \mathrm{mi}$ upstream from the mouth was $25,500 \mathrm{ft}^{3} / \mathrm{s}$ in 1957 and $18,900 \mathrm{ft}^{3} / \mathrm{s}$ in 1965 .

September 2013 peak streamflows in the Denver metropolitan area were generally well below historical records with the exception of Big Dry Creek below C-470 at Highlands Ranch (site 6), which peaked at $527 \mathrm{ft}^{3} / \mathrm{s}$ (second highest in 10 years record); Little Dry Creek near Arapahoe Road at Centennial (site 11), which peaked at $631 \mathrm{ft}^{3} / \mathrm{s}$ (third highest in 28 years); and Lena Gulch at Lakewood (site 29), which peaked at $546 \mathrm{ft}^{3} / \mathrm{s}$ (fourth highest peak in 33 years of record) (table 1, table 1-1). Streamflows in several urbanized tributaries in the Denver area were higher in July or August 2013 compared to streamflows observed in September 2013 (table 1-1); including sites on Lee Gulch (site 4), Dutch Creek (site 5); Harvard Gulch (site 14), Weir Gulch (site 15), Dry Gulch (site 16), and Lakewood Gulch (site 17). Four main stem South Platte River sites in Denver (sites 7, 13, 20, and 21) experienced annual peak streamflows for water year 2013 occurring during the September 2013 event but the peaks were not in the top 15 for their period of record (table 1-1).

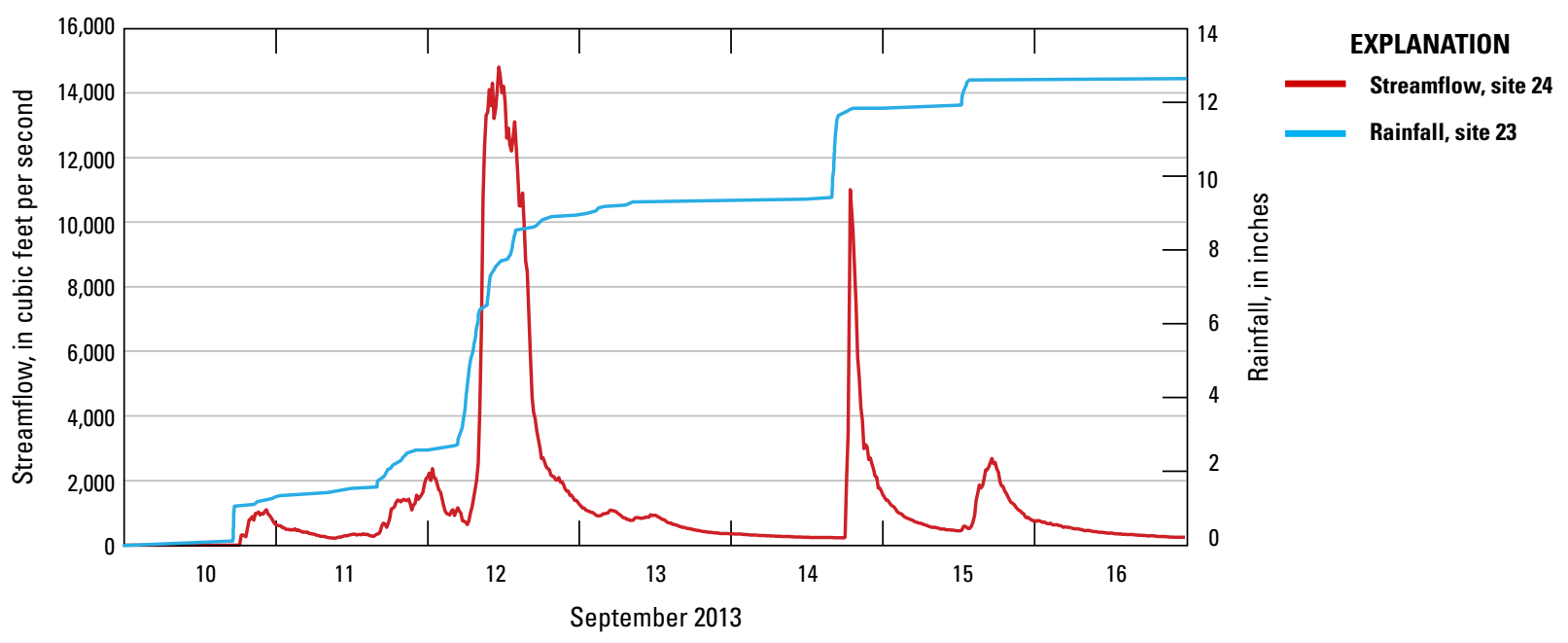

Figure 9. Streamflow for Sand Creek above Burlington Ditch near Commerce City (site 24), and cumulative rainfall for Toll Gate at 6th Avenue at Aurora (site 23), September 10-16, 2013, eastern Colorado. (Rainfall data from Urban Drainage and Flood Control District, 2014a) 
The peak of $3,930 \mathrm{ft}^{3} / \mathrm{s}$ on September 12 at the State of Colorado streamgage South Platte River at Denver (site 20) ranked 59 out of 116 peaks and was less than the 1965 peak of $40,300 \mathrm{ft}^{3} / \mathrm{s}$ (Colorado Division of Water Resources, 2014b).

Downstream from Aurora and the Denver metropolitan area, flood-peak streamflow in the main stem of the South Platte River was moderate compared to the historical record. In the South Platte River at Henderson (site 30), located about 10 mi downstream from the mouth of Sand Creek (fig. 2), the peak of $11,200 \mathrm{ft}^{3} / \mathrm{s}$ on September 13 was about one-third the magnitude of the 1973 peak of $33,000 \mathrm{ft}^{3} / \mathrm{s}$ (Colorado Division of Water Resources, 2014b). About 14 mi downstream from Henderson, a USGS streamgage on the South Platte River at Fort Lupton (site 33) that was not operational in 1973 (period of record 1929-57, 2003-13) recorded a new record peak streamflow of $10,300 \mathrm{ft}^{3} / \mathrm{s}$. Two USGS streamgages on Big Dry Creek recorded peaks in the top five for the period of record. Big Dry Creek is a plains tributary between Henderson and Fort Lupton that drains an area of mixed urban and agricultural land use north of Denver. The peak streamflow of $642 \mathrm{ft}^{3} / \mathrm{s}$ at Big Dry Creek at Westminster (site 31) ranked fourth highest out of 26 annual peaks, and the peak streamflow of $781 \mathrm{ft}^{3} / \mathrm{s}$ at Big Dry Creek at the mouth near Fort Lupton (site 32 ) ranked the highest out of 22 annual peaks.

\section{Bear Creek and Clear Creek}

At sites on the mountain tributaries of Bear Creek (site 8, above Evergreen) and Clear Creek (site 28, at Golden) west of Denver, streamflow steadily increased from September 9 through most of September 12 before increasing sharply late September 12 (fig. 10). The sharp increase coincided with 4.5 inches of rain that fell in 20 hours at a rain gage on Lookout Mountain (site 27), which is located between the two drainage basins (fig. 2). Streamgages in both basins recorded peak streamflows on September 13. The peak streamflow of $1,530 \mathrm{ft}^{3} / \mathrm{s}$ in Clear Creek at Golden (site 28) ranked only the eighth highest out of 39 years of record. Streamflow at Bear Creek above Evergreen (site 8) and Bear Creek above Bear Creek Lake near Morrison (site 10) was the highest since the streamgages were installed in 1984 and 1986, respectively. The peak streamflow at Bear Creek above Bear Creek Lake near Morrison (site 10) occurred on September 13 and was $1,800 \mathrm{ft}^{3} / \mathrm{s}$. To put this peak into historical perspective, maximum annual peak streamflows at Bear Creek at Morrison (site 9), a State of Colorado streamgage located $1.3 \mathrm{mi}$ upstream from the Bear Creek above Bear Creek Lake near Morrison streamgage (site 10), have been greater than $1,800 \mathrm{ft}^{3} / \mathrm{s}$ nine times in the 104 years of record for the station; the peak streamflow of record is $8,600 \mathrm{ft}^{3} / \mathrm{s}$ in 1896 (U.S. Geological Survey, 2014; Colorado Division of Water Resources, 2014b).

About 2 mi downstream from the Bear Creek above Bear Creek Lake near Morrison streamgage (site 10), high streamflow in Bear Creek was reduced significantly with the storage of flood flow in the Bear Creek Lake reservoir. The dam forming Bear Creek Lake reservoir is owned by the U.S. Army Corps of Engineers and was constructed in 1977 to reduce the risk of flooding in the Denver area. During the September 2013 flood event, the water level in the reservoir increased $50.4 \mathrm{ft}$ to an elevation of 5,607.8 ft, which is the highest water

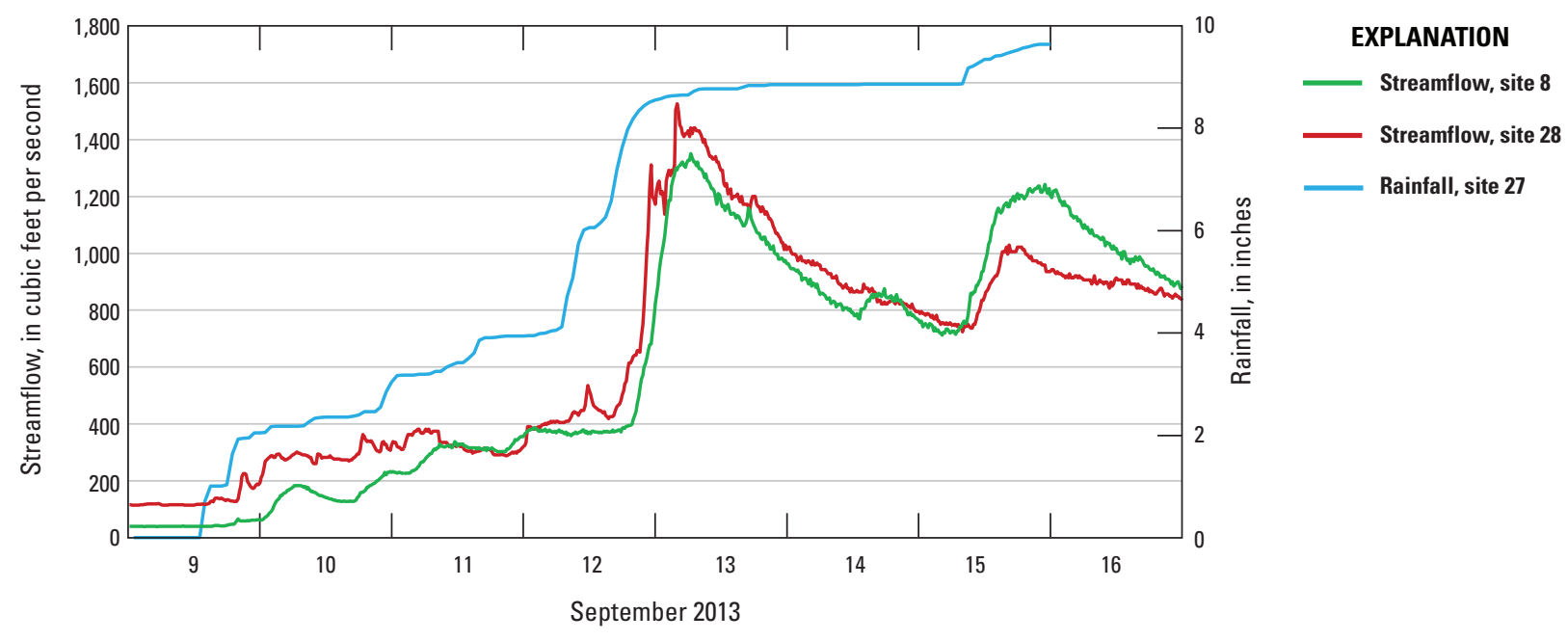

Figure 10. Streamflow for Bear Creek above Evergreen (site 8) and Clear Creek at Golden (site 28), September 9-16, 2013, and cumulative rainfall for Lookout Mountain Colorado (site 27), September 9-15, 2013, eastern Colorado. (Rainfall data from Western Regional Climate Center, 2014) 
level in the reservoir since it was completed (Brian Twombly, U.S. Army Corps of Engineers, written commun., 2014). The rise in water level equated to an additional 12,500 acre-feet (acre-ft) of water stored in the reservoir (calculated by USGS using data obtained from the Colorado Division of Water Resources, 2014b).

\section{Boulder Creek}

Flooding in the Boulder Creek Basin, a tributary basin to St. Vrain Creek, began late on September 11, about 24 hours before flooding began in the Bear Creek and Clear Creek Basins. Streamgages located near the mountain-plains interface-Boulder Creek Broadway (site 43) (located in the City of Boulder), South Boulder Creek near Eldorado Springs (site 44), and Coal Creek near Plainview (site 47) —all recorded sharp rises in stage beginning late on September 11, coinciding with increased rainfall in the foothills (Sugar Loaf Colorado, site 40, table 1-2), rising to an initial peak around midnight September 11 or early on September 12 (fig. 11). During the day of September 12, stage at each of the three streamgages had similar fluctuations before rising sharply late on September 12 to a peak level for the event (a peak on September 12 at the Coal Creek near Plainview streamgage was not confirmed because of a gap in stage record). Three USGS streamgages located in the foothills west of Boulder on Boulder Creek tributaries also recorded an initial sharp rise in stage late on September 11 before being damaged by the flood event: Fourmile Creek at Logan Mill Road near Crisman (site 41), Fourmile Creek at Orodell (site 42), and Fourmile Canyon Creek near Sunshine (site 45). Peak flows determined for the three sites by indirect measurement are listed in table 1-1. Peak streamflow at Fourmile Creek at Orodell (site 42) was $2,510 \mathrm{ft}^{3} / \mathrm{s}$, setting a new peak of record for the 22-year-old gage. A peak streamflow of 1,090 $\mathrm{ft}^{3} / \mathrm{s}$ was calculated for the relatively new Fourmile Canyon Creek near Sunshine streamgage (site 45) (2 years of record). This streamgage drains only $1.8 \mathrm{mi}^{2}$, resulting in a peak flood streamflow rate of $606 \mathrm{ft}^{3} / \mathrm{s} / \mathrm{mi}^{2}$. This was the highest streamflow rate per square mile during the September 2013 event for sites documented in this report.

Peak streamflow on September 12, 2013, as recorded at the Boulder Creek Broadway streamgage (site 43) in the City of Boulder (drainage area of $135 \mathrm{mi}^{2}$ ) was 4,970 ft/s (Urban Drainage and Flood Control District, 2014a). The peak of record for Boulder Creek in the vicinity of downtown Boulder is tied to the flood of May 29-June 1, 1894. In 1912, Metcalf \& Eddy consulting engineers of Boston estimated the peak streamflow for the 1894 event in Boulder Creek near 4th Street in Boulder (drainage area of $132 \mathrm{mi}^{2}$ ) ranged from 9,000 to $13,600 \mathrm{ft}^{3} / \mathrm{s}$ (Follansbee and Sawyer, 1948).

Stage in Boulder Creek at North 75th Street near Boulder (site 46; drainage area of $307 \mathrm{mi}^{2}$ ), located about $7 \mathrm{mi}$ downstream from the Boulder Creek Broadway streamgage (site 43), exhibited a similar pattern to the three upstream streamgages in figure 11; however, the timing of the fluctuations was delayed several hours due to the time it took for flood streamflow to travel downstream. Peak streamflow for Boulder Creek at North 75th Street near Boulder on September 13 was $8,400 \mathrm{ft}^{3} / \mathrm{s}$, which set a new peak of record for this 27-year-old streamgage.

Stage at the streamgage Boulder Creek at mouth near Longmont (site 48) peaked at 5:15 a.m. on September 13; however, an instantaneous streamflow associated with the

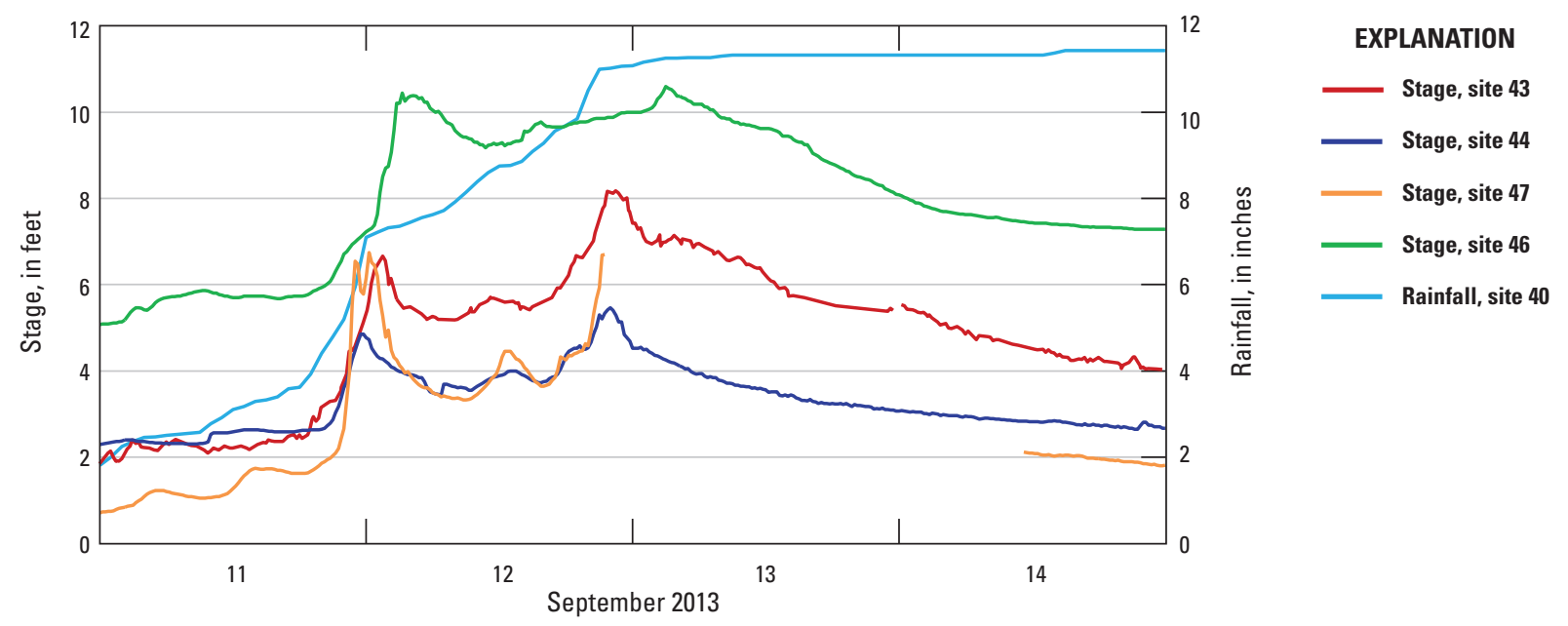

Figure 11. Stage for Boulder Creek Broadway (site 43), South Boulder Creek near Eldorado Springs (site 44), Coal Creek near Plainview (site 47), and Boulder Creek at North 75th Street near Boulder (site 46), and cumulative rainfall since September 9 at Sugar Loaf Colorado (site 40), September 11-14, 2013. (Data for sites 44 and 47 from Colorado Division of Water Resources, 2014b; data for site 43 from Urban Drainage and Flood Control District, 2014a; rainfall data for site 40 from Western Regional Climate Center, 2014) 
stage was not determined. An analysis of remotely sensed data indicates that water at the streamgage on September 13 was a combination of streamflow from both Boulder Creek and St. Vrain Creek (fig. 12); therefore, a value of streamflow corresponding to the peak stage would not accurately reflect what was flowing in Boulder Creek at the peak. A streamflow measurement of 7,920 $\mathrm{ft}^{3} / \mathrm{s}$ obtained $5 \mathrm{mi}$ upstream from the Boulder Creek at mouth near Longmont streamgage at about 12:00 p.m. on September 13 was used to estimate a daily-mean streamflow for September 13 equal to $8,910 \mathrm{ft}^{3} / \mathrm{s}$. Although an instantaneous peak was not determined, the value of the daily-mean streamflow for September 13 indicates that streamflow was at least more than twice the magnitude of the instantaneous peak streamflow of record of $4,410 \mathrm{ft}^{3} / \mathrm{s}$ from 1938 for the Boulder Creek at mouth near Longmont streamgage.

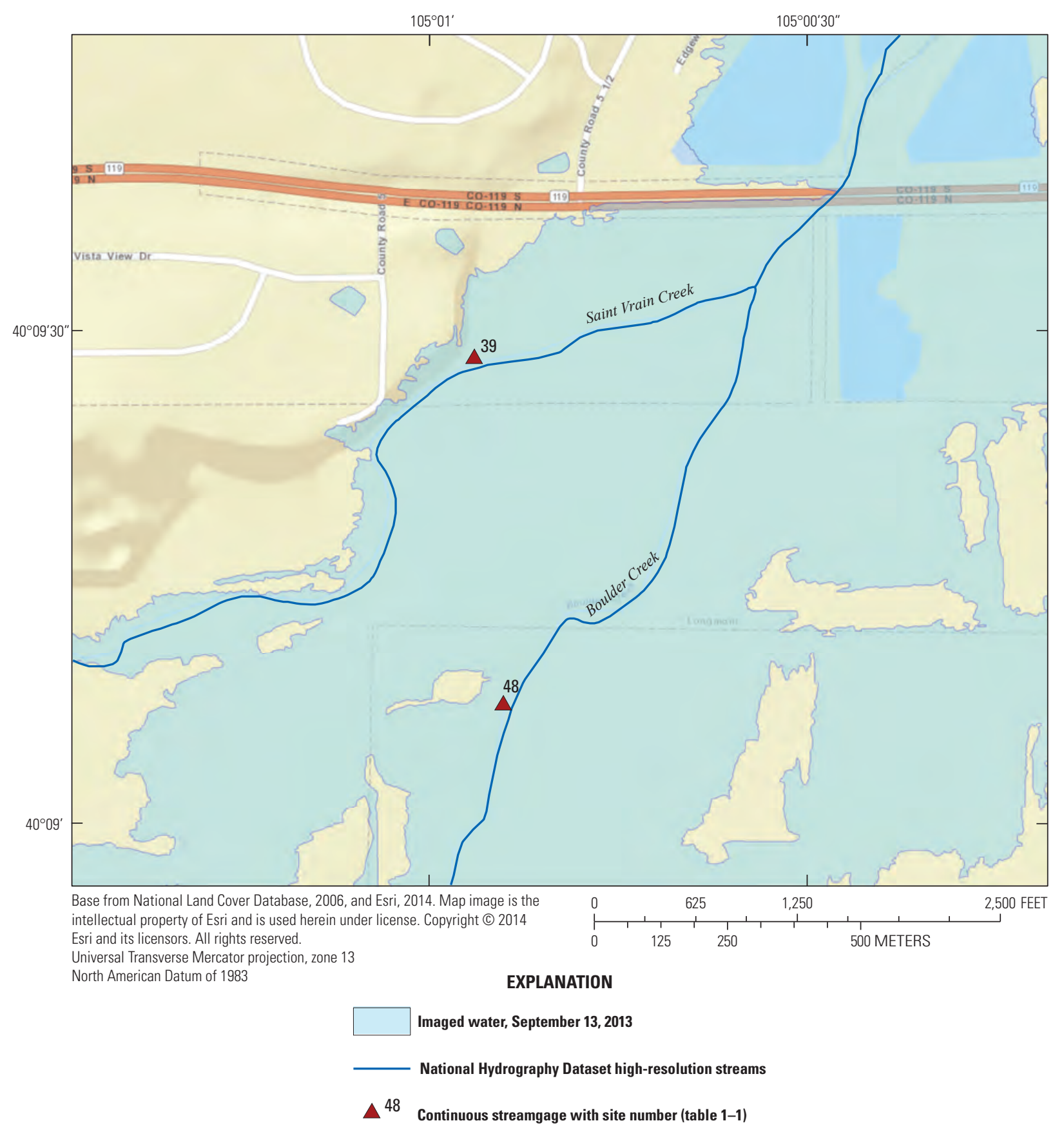

Figure 12. Extent of water surface on September 13, 2013, at the confluence of the Boulder and St. Vrain Creeks, eastern Colorado, derived from remotely sensed data (Kristine Verdin, U.S. Geological Survey, written commun., 2014). 


\section{St. Vrain Creek}

In the St. Vrain Creek (excluding Boulder Creek) and Big Thompson River Basins, most of the streamgages operated by the USGS and State of Colorado Division of Water Resources were damaged or destroyed during the September 2013 flood and few captured a continuous record of stage or streamflow for the event. Two headwaters streamgages, Middle St. Vrain at Peaceful Valley (site 34) and Big Thompson River below Moraine Park near Estes Park (site 51), recorded continuous records of stage for the event that had patterns similar to that observed in the Boulder Creek Basin where stream stage began to increase more quickly late in the day on September 11 rising to an initial peak on September 12 (fig. 13A). The increased stage coincided with increased rainfall at Johnny Park (site 35) located in the foothills of the St. Vrain Creek Basin. After a slight recession on September 12, stage at sites 34 and 51 increased to a peak for the event early on September 13 (fig. 13A).

An area of high rainfall west of Lyons (fig. 6) located over the St. Vrain Creek Basin produced large amounts of runoff that became concentrated in the main stem of the St. Vrain Creek at Lyons. The State of Colorado streamgage in Lyons (site 36) recorded an initial sharp rise in flood waters beginning at 8:00 p.m. on September 11, 2013. By 11:00 p.m. that evening, the gage had suffered extensive damage and had stopped reporting streamflow readings. Several other gages on St. Vrain Creek recorded the leading edge of the flood wave as it progressed downstream from Lyons; however, these gages also stopped reporting streamflow either shortly before or when they were destroyed by flood waters; St. Vrain Creek at Longmont (site 37), St. Vrain Creek below Longmont (site 39), and St. Vrain Creek at mouth near Platteville (site 50) (fig. 13B).
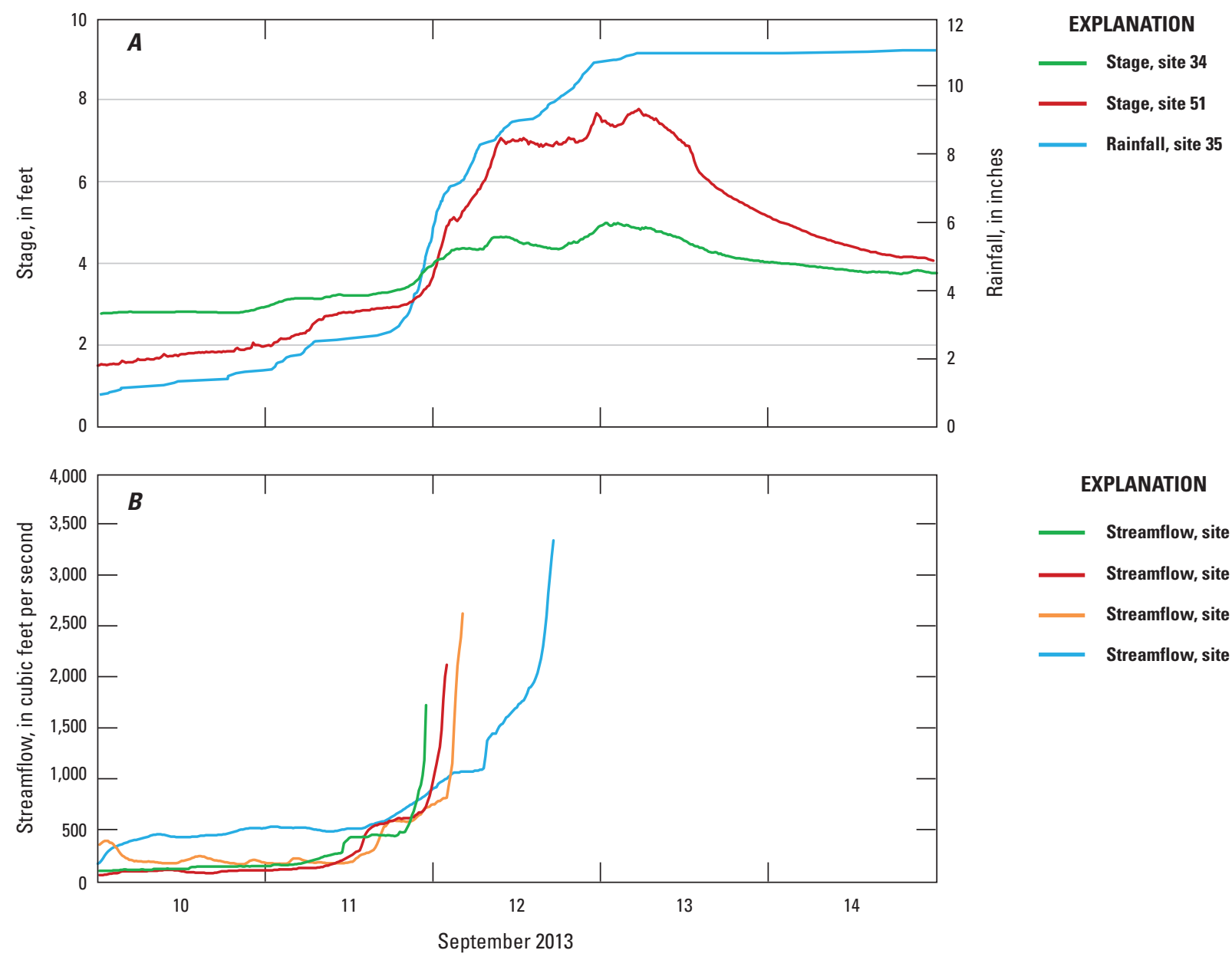

EXPLANATION

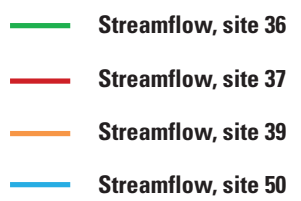

Figure 13. A, Stage for Middle St. Vrain at Peaceful Valley (site 34) and Big Thompson River below Moraine Park near Estes Park (site 51), and cumulative rainfall since September 9 at Johnny Park (site 35), September 10-14, 2013; and B, streamflow for St. Vrain Creek at Lyons (site 36), St. Vrain Creek at Longmont (site 37), St. Vrain Creek below Longmont (site 39), and St. Vrain Creek at mouth near Platteville (site 50), September 10-14, 2013. (Data for sites 34, 36, 37, and 50 from Colorado Division of Water Resources, 2014b; rainfall data for site 35 from Urban Drainage and Flood Control District, 2014a.) 
When applying the FaSTMECH two-dimensional model for determining peak streamflow in the St. Vrain Creek at Lyons (site 36), there was evidence that high-water marks surveyed on the left bank (looking downstream) may have been influenced by an adjacent highway and water diversion and canal systems. Therefore, it was thought that high-water marks surveyed on the right bank would provide a better predictor of peak streamflow. Under this assumption, the best overall calibration of the model was achieved using only right-bank high-water marks, and a surface roughness drag coefficient equal to 0.01 , resulting in a peak streamflow of $23,800 \mathrm{ft}^{3} / \mathrm{s}$, and a root-mean square error of 0.10 for the fit between observed and simulated water-surface elevations. For reference, a drag coefficient of 0.01 corresponds approximately to a Manning's $n$ of 0.036 where the depth is $6.5 \mathrm{ft}$ which is a good average value for the modeled reach of the St. Vrain Creek in Lyons. The peak streamflow was assigned an uncertainty of plus or minus 10 percent (Richard McDonald, U.S. Geological Survey, written commun., 2014). The peak streamflow of $23,800 \mathrm{ft}^{3} / \mathrm{s}$ is more than double the record peak of $10,500 \mathrm{ft}^{3} / \mathrm{s}$ recorded in 1941.

Downstream from the confluence with Left Hand Creek (located about $10 \mathrm{mi}$ downstream from Lyons), the peak streamflow in St. Vrain Creek was estimated to be $31,700 \mathrm{ft}^{3} / \mathrm{s}$ at St. Vrain Creek at North 119th Street near Longmont (site 38), and downstream from the confluence with Boulder Creek, the peak was estimated to be $37,000 \mathrm{ft}^{3} / \mathrm{s}$ at St. Vrain Creek at I-25 near Longmont (site 49). The peak streamflow at site 38 was calculated using the slope-area method and was assigned an uncertainty of plus or minus 15 percent. The peak streamflow at site 49 was calculated using the contracted opening and culvert methods and was assigned an uncertainty of plus or minus 15 to 25 percent. Flood-peak stage and streamflow data were not determined for the State of Colorado streamgage St. Vrain Creek at mouth near Platteville (site 50), located about $12 \mathrm{mi}$ downstream from Interstate 25 (Colorado Division of Water Resources, 2014b). The historical peak of record at the mouth of St. Vrain Creek is $11,300 \mathrm{ft}^{3} / \mathrm{s}$ dating back to 1938. The peak streamflow of $37,000 \mathrm{ft}^{3} / \mathrm{s}$ at St. Vrain Creek at I-25 near Longmont (site 49) may be an indication that streamflow was higher than $11,300 \mathrm{ft}^{3} / \mathrm{s}$ at the mouth in September 2013; however, there was most certainly some attenuation of the peak in the lower reaches of the St. Vrain Creek as it flowed for about $12 \mathrm{mi}$ through relatively flat agricultural land.

\section{Big Thompson River}

The largest flood in the Big Thompson River since records began in 1888 happened on July 31, 1976 (U.S. Geological Survey, 2014). That flood resulted from as much as 7.5 inches of rain that fell in about 1 hour over the middle Big Thompson River Basin and to a lesser extent in parts of the Cache la Poudre River Basin (Jarrett and Costa, 2006). During the event, a peak streamflow of $31,200 \mathrm{ft}^{3} / \mathrm{s}$ was estimated for the Big Thompson River at mouth of canyon near Drake (site 52). For the September 2013 flood, the USGS estimated peak streamflow at this same site to be $16,200 \mathrm{ft}^{3} / \mathrm{s}$; the second highest peak on record. Farther downstream, the USGS calculated a peak streamflow of 19,000 $\mathrm{ft}^{3} / \mathrm{s}$ at the Big Thompson River at Loveland (site 53), which is the highest streamflow recorded for this site since it was established in 1979, shortly after the 1976 flood event.

\section{Cache la Poudre River}

Flooding in the Cache la Poudre River peaked on September 13, 2013. A peak streamflow of $9,730 \mathrm{ft}^{3} / \mathrm{s}$ was recorded at the Cache La Poudre River at mouth of canyon near Fort Collins streamgage (site 56) located $11.4 \mathrm{mi}$ upstream from Fort Collins (Colorado Division of Water Resources, 2014b). The State of Colorado streamgage at the mouth of Poudre Canyon is one of the longest operating streamgages in the State and has 131 annual streamflow peaks on record dating back to 1882 . The 2013 peak ranks the fourth highest out of the 131 peaks and is slightly less than one-half the value of the peak of record of $21,000 \mathrm{ft}^{3} / \mathrm{s}$ set in 1891 . That peak resulted in the failure of Chambers Lake Dam (not labeled on a figure) (Follansbee and Sawyer, 1948). Farther downstream, peak streamflow in the Cache la Poudre River at Fort Collins (site 59) was $8,140 \mathrm{ft}^{3} / \mathrm{s}$. The 2013 peak in the Cache la Poudre River at Fort Collins is the highest peak recorded since the gage was established in 1975 (39 years of record).

Although the 1976 flood is most commonly associated with flooding in the Big Thompson River, the 1976 event did cause a significant peak in the Cache la Poudre River at Fort Collins (site 59) of 5,700 ft $3 / \mathrm{s}$ (U.S. Geological Survey, 2014). This value ranks the fourth highest in the 39-year history of the station. The 1976 and 2013 peaks were both the result of rainfall events, and a comparison of data for the two events highlights the difference in storm characteristics (fig. 14).

The flashy streamflow peak of 1976 (fig. 14A) is indicative of a short-duration, high intensity rainfall event. A record of continuous rainfall during the 1976 event was obtained 11 mi northwest of Fort Collins in the Cache la Poudre River Basin (McCain and Shroba, 1979). Rainfall data for this site show that, beginning late on July 31, 1976, about 6.1 inches of rain fell in about a 4-hour period (fig 14A), which translates to a rate of about 1.5 inches per hour. Shortly after this period of intense rainfall, streamflow in the Cache la Poudre River at Fort Collins increased by about 5,600 ft $3 / \mathrm{s}$ in just 2.5 hours, or an average increase of $2,240 \mathrm{ft}^{3} / \mathrm{s}$ per hour. With a temporary cessation in rainfall, streamflow dropped relatively quickly following the peak.

Compared to the 1976 peak, the more sustained and broader 2013 streamflow peak (fig. 14B) is indicative of a longer duration, lower intensity rainfall event. Rainfall that began on September 9, 2013, at another site northwest of Fort Collins (site 57) had accumulated to just over 2 inches 

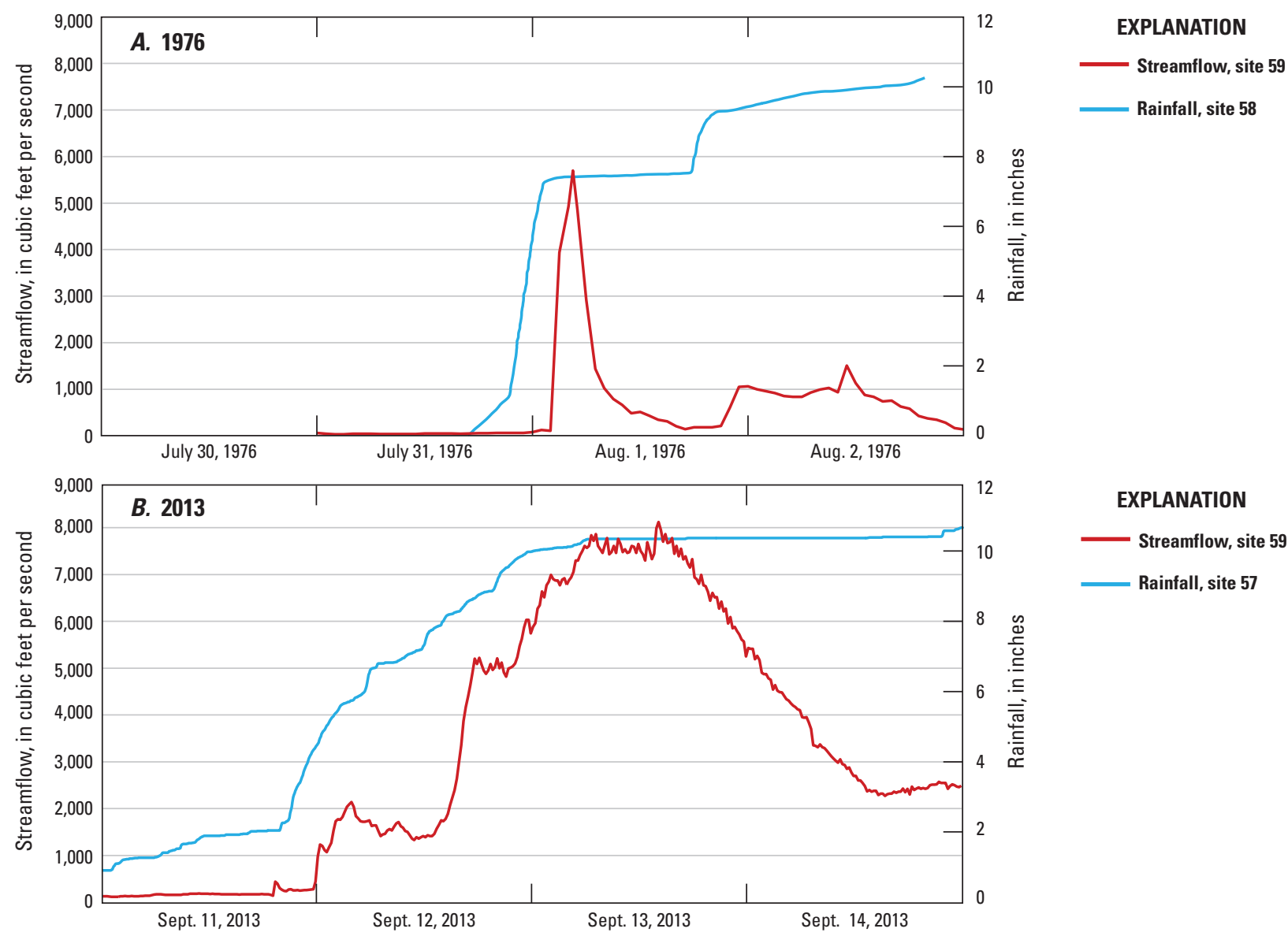

Figure 14. A, Cumulative rainfall 11 miles northwest of Fort Collins (site 58), and streamflow for the Cache la Poudre River at Fort Collins (site 59), July 31-August 2, 1976; and B, cumulative rainfall since September 911.8 miles northwest of Fort Collins (site 57), and streamflow for the Cache la Poudre River at Fort Collins (site 59), September 11-14, 2013. (Data for 1976 from McCain and Shroba, 1979)

on September 11 (fig 14B). From late September 11 through September 12, an additional 7.7 inches of rain fell, translating to a rate of about 0.3 inches per hour for this time period. The largest increase in streamflow associated with this rainfall occurred between midday September 12 to about 7:00 a.m. on September 13 when streamflow increased by about $360 \mathrm{ft}^{3} / \mathrm{s}$ per hour.

\section{South Platte River - Near Greeley to Mouth}

On September 14, 2013, high streamflow coming out of the Denver metropolitan area in the main stem South Platte River in combination with flood flows from the mountain tributaries probably resulted in a new record peak streamflow in the main stem of the South Platte River near Greeley. Unfortunately, a streamgage on the South Platte River near Kersey (site 61) located about 6.5 mi downstream from Greeley was damaged during the event and did not capture a peak streamflow (Russell Stroud, Colorado Division of Water Resources, written commun., 2014). A peak of $60,000 \mathrm{ft}^{3} / \mathrm{s}$ on September 15 for the South Platte River at Fort Morgan (site 64) about $45 \mathrm{mi}$ downstream from Kersey is the basis for assuming record flow occurred near Greeley and Kersey. The relation between peak streamflow in the South Platte River near Kersey (site 61) and at Fort Morgan (site 64) or at Balzac (site 65, located 20 mi downstream from Fort Morgan) varies depending on the amount of inflow between the gages from the intermittent plains streams Crow, Kiowa, Bijou, and Beaver Creeks (fig. 1). Peak streamflow in the South Platte River at Fort Morgan (1935 flood) and at Balzac (1965 flood) was much greater than the peak streamflow in the South Platte River near Kersey during those events (fig. 15A, $B$ ) because of a large amount of inflow from Bijou Creek. Peak streamflow in Bijou Creek near Wiggins (site 63) was 282,900 ft $3 / \mathrm{s}$ in 1935 and 466,000 ft $\mathrm{ft}^{3} / \mathrm{s}$ in 1965 (Matthai, 1969). During the 1973 flood, which is the flood of record in the South Platte River near Kersey, peak streamflow near Kersey was $31,500 \mathrm{ft}^{3} / \mathrm{s}$, but only $20,300 \mathrm{ft}^{3} / \mathrm{s}$ at Balzac (fig. 15C). The smaller peak in the South Platte River at Balzac in 1973, compared to near Kersey, may indicate that there was very little inflow between the two sites and that 


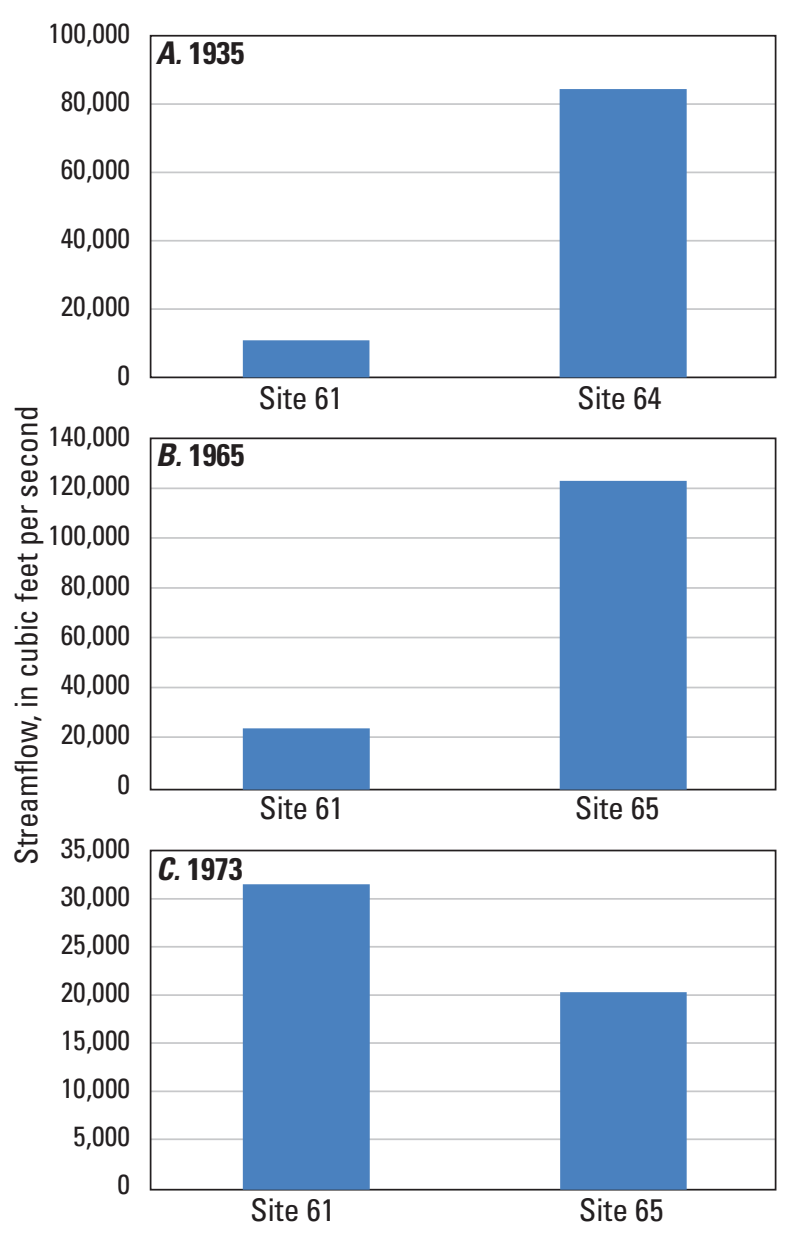

Figure 15. Peak streamflow in the South Platte River near Kersey (site 61) compared to peak streamflow in the $A$, South Platte River at Fort Morgan (site 64), 1935; $B$, South Platte River at Balzac (site 65), 1965; and $C$, South Platte River at Balzac (site 65), 1973. the amplitude of the flood wave had probably attenuated as it traveled down the main stem South Platte River from near Kersey to Balzac. During the September 2013 event minimal inflow to the main stem South Platte River was observed between the streamgages located near Kersey (site 61) and at Fort Morgan (site 64) (Brent Schantz, Colorado Division of Water Resources, oral commun., 2015). Without additional inflow between the two sites, the relation between streamflow near Kersey and at Fort Morgan was probably similar to the 1973 flood and it is possible that streamflow in the main stem South Platte River near Kersey (site 61) was at least as large as at Fort Morgan $\left(60,000 \mathrm{ft}^{3} / \mathrm{s}\right)$. If that assumption is correct, it would mean there was probably record streamflow at the South Platte River near Kersey streamgage surpassing the peak of record of 31,500 $\mathrm{ft}^{3} / \mathrm{s}$ from 1973 (109 annual peaks on record between 1902-2012).

Several State of Colorado and USGS streamgages recorded the progression of the flood crest as it moved down the lower South Platte River in eastern Colorado and in the Platte River across Nebraska (fig. 16). River stage in the South Platte River near Weldona (site 62) began to rise steadily early on September 12 before rising sharply to its peak on September 14. Similar to the stage near Weldona (site 62), stage in the South Platte River at Fort Morgan (site 64) increased by about 10 feet in 3 hours on September 14. The flood crest exited Colorado on September 18, 2013, after peaking in the South Platte River at Julesburg (site 67) on September 18 at $21,800 \mathrm{ft}^{3} / \mathrm{s}$, the fifth highest flow in 109 years of record (U.S. Geological Survey, 2014). Two hundred mi downstream from Greeley, and at least that far downstream from the source of the flood runoff, stage rose more than $10 \mathrm{ft}$ on September 19 in the South Platte River at Roscoe, Nebr. (site 68). About 400 mi downstream from Greeley, stage in the Platte River at Grand Island, Nebr. (site 70) rose almost $4 \mathrm{ft}$ from September 25 to September 29, 2013.

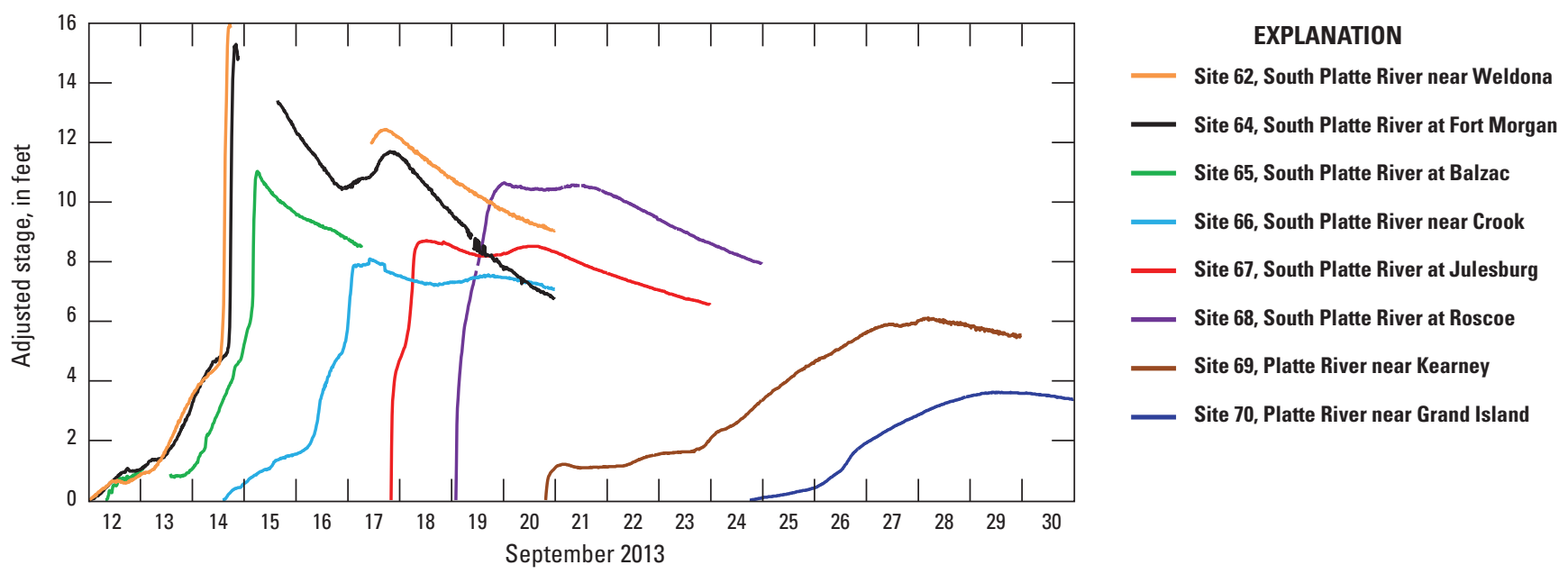

Figure 16. Stage, adjusted to a common base of 0 feet, for selected streamgages (sites 62, 64-70; site numbers in table 1-1) along the lower South Platte and Platte Rivers, September 12-30, 2013. Data for site 65 obtained 5.6 mi upstream from site 65. Data for sites 62, 65-67 from Colorado Division of Water Resources, 2014b. 


\section{Description of Flooding in the Fountain Creek Basin}

Flooding in the Fountain Creek Basin (figs. 1 and 3) primarily occurred in Fountain Creek from southern Colorado Springs to its confluence with the Arkansas River in Pueblo, in lower Monument Creek in Colorado Springs, and in several mountain tributaries. All of the streamgages in the Fountain Creek Basin recorded streamflow peaks on September 12 or 13,2013 , coinciding with the period of maximum rainfall. Twelve streamgages in the Fountain Creek Basin with at least 10 years of record had peak streamflows during the September 2013 flood that ranked in the top five for the period of record, and 4 of those sites set a new record peak streamflow (table 2 , table 1-1).

Flooding originated in the upper part of the Fountain Creek Basin coinciding with heavy rainfall that occurred in and around the Colorado Springs metropolitan area. Data from a network of USGS rain gages indicate that rainfall totals for September 10-16, 2013, generally increased from east to west across Colorado Springs with the highest amounts occurring in the foothills south and southwest of the city (fig. 17). Data for selected sites (fig. 18) indicate that rainfall in the foothills began late on September 10 with most of the rain occurring from late on September 11 through the morning of September 13; from highest totals to lowest: Rod and Gun meteorologic station at Fort Carson (site 112), Bear Creek near Colorado Springs (site 97), Oak Meadow Park meteorologic station at Colorado Springs (site 107), Upper Williams Canyon met above Manitou Springs Canyon (site 75), Lower Waldo Canyon met above Manitou Springs (site 74), West Monument Creek at U.S. Air Force Academy (site 84), and Upper Waldo Canyon met above Cascade (site 73). To the east and southeast of Colorado Springs, rainfall primarily occurred from late on September 12 through the morning of September 13 at Penrose met at Penrose Elementary at Colorado Springs (site 94), Pine Creek met site below Old Ranch Road at Colorado Springs (site 83), Ridgeview met below Dublin Blvd. at Colorado Springs (site 102), and Fountain Creek at Security (site 108). All of the rain gages in figure 18 recorded additional rainfall on September 15.

On the east side of Colorado Springs, the relatively small amounts of rainfall recorded in the Sand Creek Basin (sites 101-105) was not enough to produce flooding, and streamflow in Sand Creek above mouth at Colorado Springs (site 106) was actually higher in August 2013 compared to September 2013. A similar situation existed at most streamgages in the Monument Creek Basin where streamflow was higher in August 2013 compared to September 2013, including three sites on the main stem of Monument Creek (sites 81, 85, and 90), and two sites on Cottonwood Creek (sites 87 and 88). Only two streamgages with more than 10 years record in the Monument Creek Basin had peak streamflows in September 2013 that ranked in the top five for the period of record; West Monument Creek at U.S. Air Force Academy (site 84) where a peak of $151 \mathrm{ft}^{3} / \mathrm{s}$ ranked second highest in 44 years of record, and Monument Creek at Bijou Street at Colorado Springs (site 96), where a peak of $6,150 \mathrm{ft}^{3} / \mathrm{s}$ ranked the third highest in the 11 years of record (table 2, table 1-1).

Table 2. Peak streamflow data that ranked in the top five for the period of record at selected streamgages with at least 10 years of record in the Fountain Creek Basin, September, 2013.

[no., number; USGS, U.S. Geological Survey; $\mathrm{ft}^{3} / \mathrm{s}$, cubic feet per second]

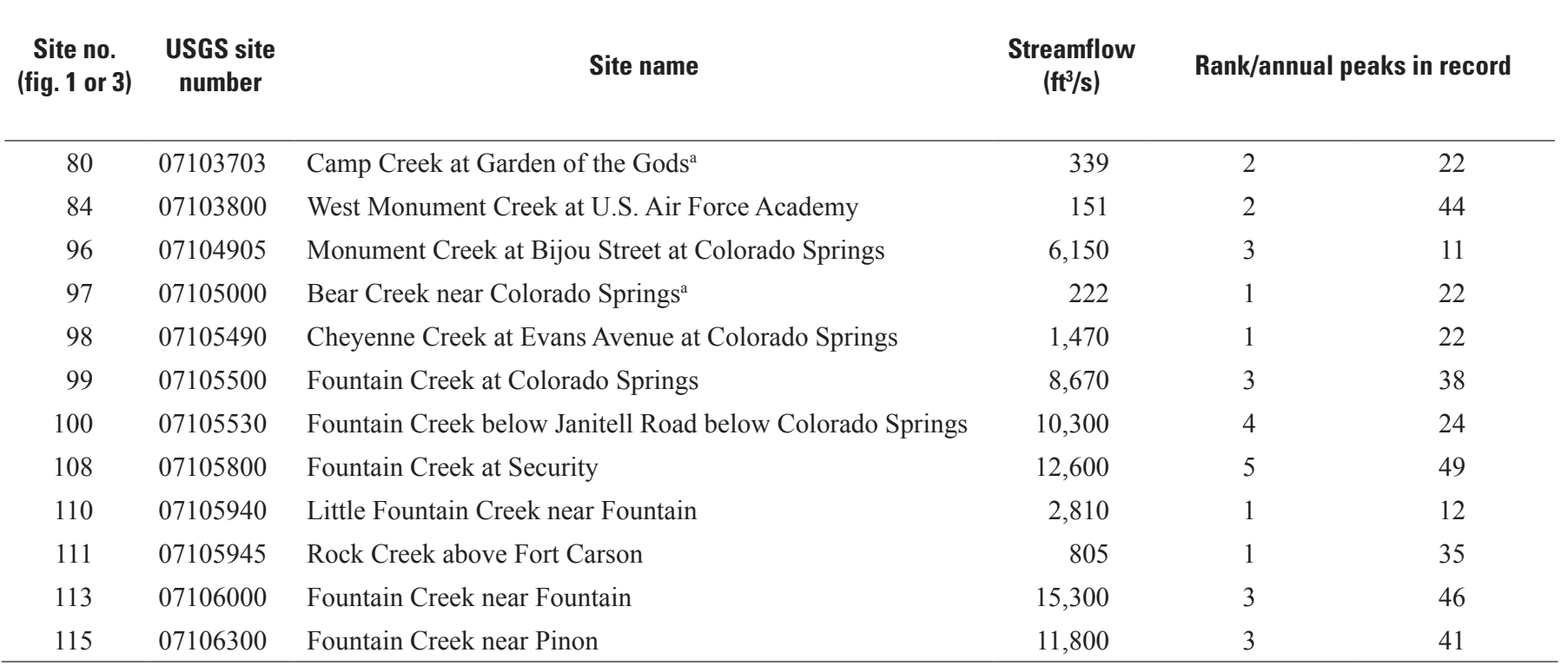

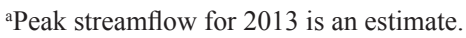




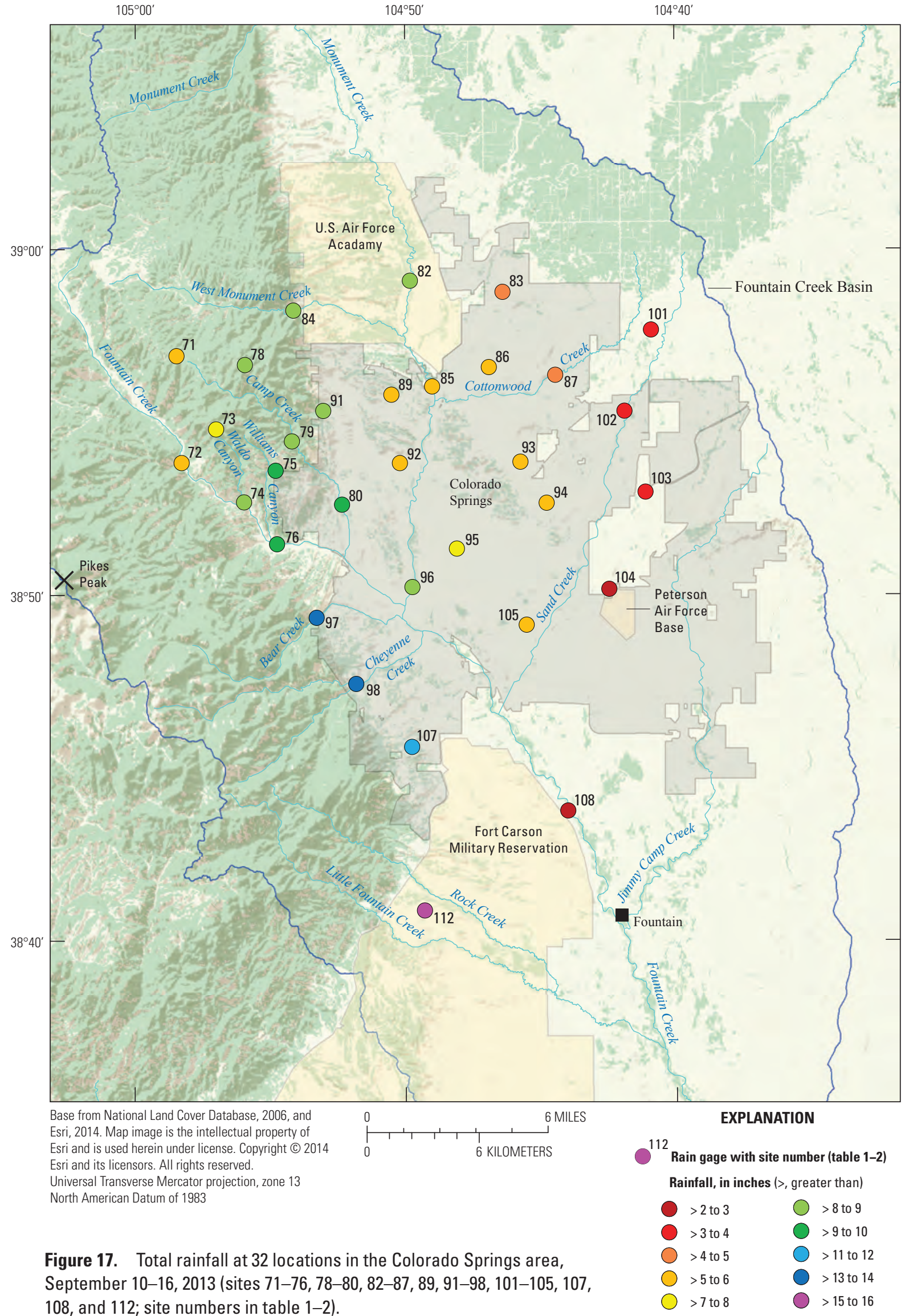




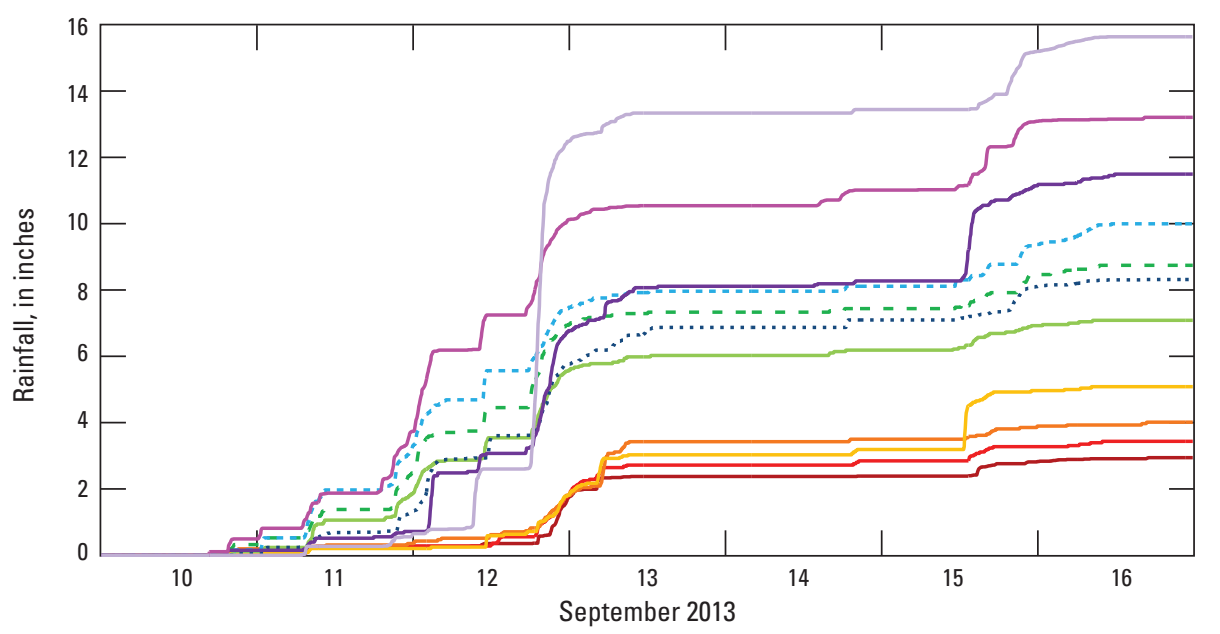

EXPLANATION

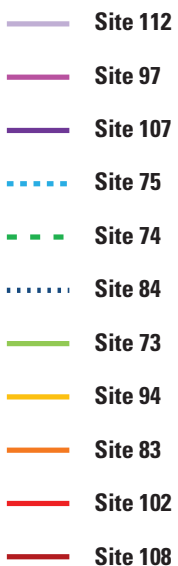

Figure 18. Cumulative rainfall for selected sites in the Colorado Springs area, September 10-16, 2013 (sites 73-75, 83, 84, $94,97,102,107,108$, and 112; site numbers in table 1-2).

Rainfall totaling between 9 and 14 inches produced new record peak streamflows at two mountain-tributary streamgages on the west side of Colorado Springs; Bear Creek near Colorado Springs (site 97), and Cheyenne Creek at Evans Avenue at Colorado Springs (site 98); and a peak ranking second at Camp Creek at Garden of the Gods (site 80). All three streamgages have 22 years of record (table 2, table 1-1).

In a 32-mi reach of Fountain Creek extending from Colorado Springs to Piñon, peak streamflows in the top five for the period of record were documented at five streamgages having at least 10 years of record. Peak streamflow was third highest in 38 years at Fountain Creek at Colorado Springs (site 99), fourth highest in 24 years at Fountain Creek below Janitell Road below Colorado Springs (site 100), fifth highest in 49 years at Fountain Creek at Security (site 108), third highest in 46 years at Fountain Creek near Fountain (site 113), and third highest in 41 years at Fountain Creek near Pinon (site 115) (table 2, table 1-1).

The flood peaks initially recorded in Fountain Creek at Colorado Springs (site 99) were also recorded about 2 to 4 hours later about $18 \mathrm{mi}$ farther downstream at the streamgage Fountain Creek near Fountain (site 113) (fig. 19). The first two streamflow peaks recorded at the gage near Fountain (site 113) on September 12 of about 10,800 and $4,800 \mathrm{ft}^{3} / \mathrm{s}$ (fig. 19) were about 25 percent larger than the upstream corresponding peaks at Colorado Springs (site 99). The third peak recorded at the gage near Fountain (site 113) early on September 13 of 15,300 $\mathrm{ft}^{3} / \mathrm{s}$ was about 88 percent larger than the upstream corresponding peak at Colorado
Springs (site 99). The proportionally greater volume of water for this particular peak is attributed to additional inflow from Little Fountain Creek located on the west side of the basin. Streamflow in the Little Fountain Creek Basin rose to record levels late on September 12 following intense rainfall. Figure 19 shows cumulative rainfall for a site located in the Little Fountain Creek Basin, Rod and Gun meteorologic station at Fort Carson (site 112), where about 9.8 inches of rain fell during the last 6 hours of September 12. Streamflow at Rock Creek above Fort Carson Reservation (site 111), located in the upper reaches of the Little Fountain Creek Basin, peaked at $805 \mathrm{ft}^{3} / \mathrm{s}$ and was the highest streamflow recorded in the 35-year history of the station. Upstream from the confluence with Rock Creek at Little Fountain Creek near Fountain (site 110), streamflow peaked at $2,810 \mathrm{ft}^{3} / \mathrm{s}$, ranking as the highest peak in the 12-year history of the station.

The peak of $15,300 \mathrm{ft}^{3} / \mathrm{s}$ at the Fountain Creek near Fountain streamgage (site 113) that occurred at 1:35 a.m. on September 13 was the highest streamflow recorded in the Fountain Creek Basin during the September 2013 event and ranks as the third highest in the 46 years of record for the station, with the peak of record being 22,100 ft $3 / \mathrm{s}$ from 1940 . The flood crest was recorded about 12 hours later on September 13 near the mouth of the Fountain Creek Basin in the City of Pueblo. Streamflow in Fountain Creek at Pueblo (site 116) peaked at $11,800 \mathrm{ft}^{3} / \mathrm{s}$ and ranked only thirteenth highest out of 74 annual peaks with the highest on record being $47,000 \mathrm{ft}^{3} / \mathrm{s}$ in 1965 (table 1-1). 


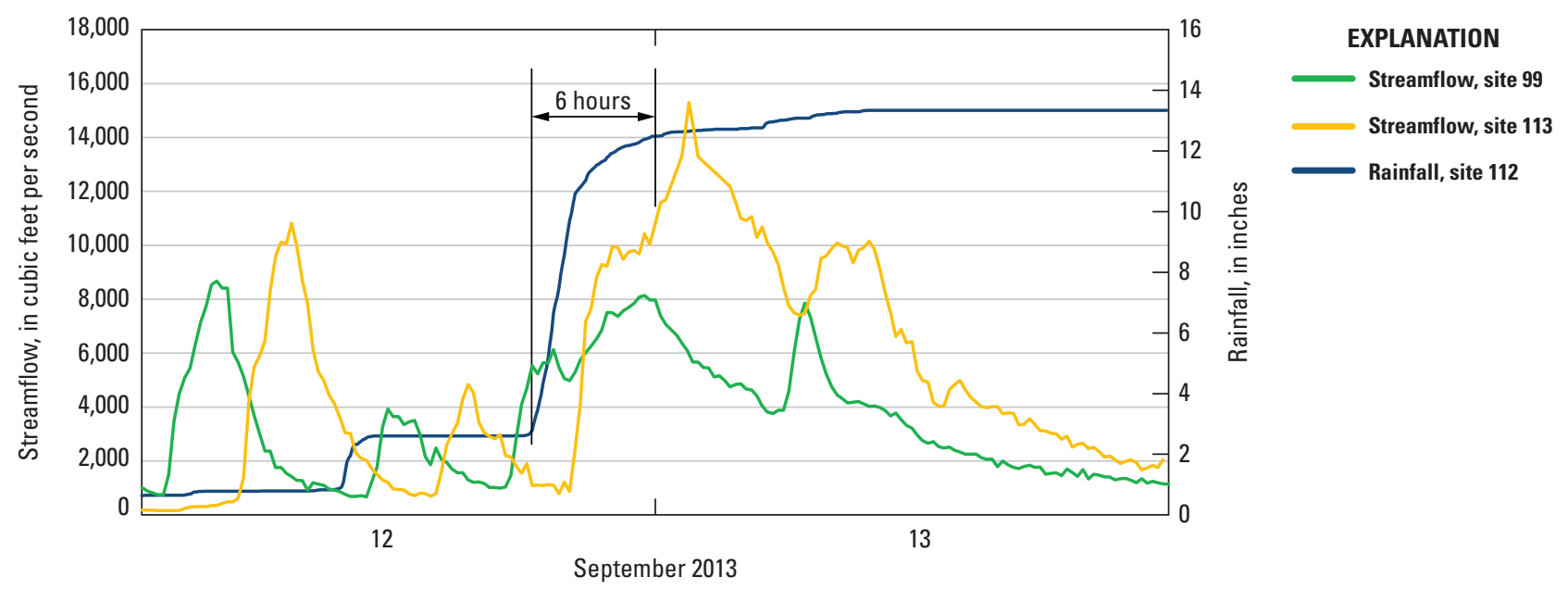

Figure 19. Streamflow in Fountain Creek at Colorado Springs (site 99), Fountain Creek near Fountain (site 113), and cumulative rainfall since September 10 at the Rod and Gun meteorologic station at Fort Carson (site 112), September 12-13, 2013.

\section{Summary}

Excessive rainfall caused major flooding during September 9-18, 2013, in eastern Colorado including a large part of the South Platte River Basin, primarily north of and downstream from Denver, and in the Fountain Creek Basin, a tributary to the Arkansas River. The floods resulted in several fatalities, more than 31,000 damaged or destroyed structures, and an estimated 3 billion dollars in damages. On September 9, 2013, rain began to fall in eastern Colorado as a large lowpressure system pulled plumes of tropical moisture northward from the Pacific Ocean and the Gulf of Mexico. By September 16,2013 , as much as 12 to 20 inches of rain had fallen in the foothills of the Front Range of the Southern Rocky Mountains and adjacent plains near Colorado Springs, Colorado, north to the Colorado-Wyoming border. Maximum rainfall in the South Platte River Basin was concentrated in the foothills in an area extending from west of Denver to north of Estes Park and in an area east of Denver that included the City of Aurora. The annual exceedance probability for maximum 24-hour rainfall for parts of the South Platte River Basin was as small as 0.1 percent, indicating the rarity of the rainfall event. In the vicinity of Colorado Springs in the upper Fountain Creek Basin, rainfall totals for September 10-16 ranged from about 2 to 16 inches. On September 12, 2013, a total of 11.85 inches of rain was recorded at a U.S. Geological Survey (USGS) rain gage in the Fountain Creek Basin, setting a new daily-record amount for Colorado.

The USGS documented peak stage, streamflow, or both from the flood event at 80 sites located on selected rivers and streams in the South Platte River and Fountain Creek Basins and on the Platte River in Nebraska. Most of the data were collected by the USGS at streamgages or derived from field surveys of high-water marks and channel geometry as part of an indirect measurement of streamflow. Some of the data were obtained from other sources. Rainfall data were collected for 37 sites; 5 sites in the South Platte River Basin and 32 sites in the Fountain Creek Basin.

Flooding in the South Platte River Basin was primarily contained to select streams in Aurora and the Denver metropolitan area, most of the mountain tributaries joining the main stem South Platte River from Denver to Greeley, and in the main stem South Platte River from Denver to the ColoradoNebraska State line. The majority of flood-peak streamflows occurred on September 12 or 13, 2013, coinciding with the period of maximum rainfall. Twenty-nine streamgages in the South Platte River Basin with at least 10 years of record had peak streamflows during the September 2013 flood that ranked in the top five for the period of record, and 13 of those sites set a new record peak streamflow.

In Aurora, where about 15 inches of rain fell, streamflow in Toll Gate Creek (a tributary to Sand Creek) peaked at 5,470 cubic feet per second $\left(\mathrm{ft}^{3} / \mathrm{s}\right)$. Downstream from Aurora near the confluence with the South Platte River, Sand Creek peaked at 14,900 $\mathrm{ft}^{3} / \mathrm{s}$ on September 12, which was the highest streamflow since at least 1992, but less than a peak of 25,500 $\mathrm{ft}^{3} / \mathrm{s}$ that occurred in 1957 about 4 miles (mi) upstream from the mouth. With the exception of sites on Big Dry Creek in Highlands Ranch, Little Dry Creek in Centennial, and Lena Gulch in Lakewood, September 2013 peak streamflows in the Denver metropolitan area were generally well below historical records. The peak of 3,930 ft $\mathrm{ft}^{3} / \mathrm{s}$ on September 12 at the State of Colorado streamgage South Platte River at Denver ranked 59 out of 116 peaks and was less than the 1965 peak of $40,300 \mathrm{ft}^{3} / \mathrm{s}$. 
Ten of the 13 streamgages in the South Platte River Basin with new record peak streamflows were located on the mountain tributaries; Bear Creek, Fourmile Creek, Boulder Creek, St. Vrain Creek, the Big Thompson River, and the Cache la Poudre River. At a USGS streamgage west of Denver on Bear Creek, streamflow reached $1,800 \mathrm{ft}^{3} / \mathrm{s}$. At a State of Colorado streamgage located nearby upstream, Bear Creek has had maximum annual peaks greater than $1,800 \mathrm{ft}^{3} / \mathrm{s}$ nine times in the past 104 years.

In Boulder Creek, a tributary to St. Vrain Creek, streamflow in the City of Boulder peaked on September 12 at $4,970 \mathrm{ft}^{3} / \mathrm{s}$ at a station operated by the Urban Drainage and Flood Control District, which was much less than the 1894 peak estimated to be between 9,000 to $13,600 \mathrm{ft}^{3} / \mathrm{s}$. Peak streamflow at the mouth of Boulder Creek was not determined, but an estimate of a daily-mean streamflow for September 13 equal to $8,910 \mathrm{ft}^{3} / \mathrm{s}$ indicates the peak was probably at least two times the magnitude of the instantaneous peak of record of $4,410 \mathrm{ft}^{3} / \mathrm{s}$ recorded in 1938 . Peak streamflow in St. Vrain Creek at Lyons was estimated by the USGS to be $23,800 \mathrm{ft}^{3} / \mathrm{s}$, which is more than double the previous peak of $10,500 \mathrm{ft}^{3} / \mathrm{s}$ recorded in 1941.

For the September 2013 flood, the USGS calculated a peak streamflow of $16,200 \mathrm{ft}^{3} / \mathrm{s}$ for the Big Thompson River at mouth of canyon near Drake streamgage, which was the second highest peak in 90 years of record and about one-half the magnitude of the peak of 31,200 $\mathrm{ft}^{3} / \mathrm{s}$ from July 31, 1976. Flood streamflows in the Cache la Poudre River peaked on September 13 at 9,730 $\mathrm{ft}^{3} / \mathrm{s}$ at the mouth of Poudre Canyon. The State of Colorado streamgage at the mouth of Poudre Canyon is one of the oldest gages in the State and has 131 annual streamflow peaks on record dating back to 1882 . The 2013 peak ranks the fourth highest out of the 131 peaks and is slightly less than one-half the value of the peak of record of $21,000 \mathrm{ft}^{3} / \mathrm{s}$ set in 1891 , which resulted from the failure of Chambers Lake Dam.

Streamflow in the main stem South Platte River combined with inflow from the mountain tributaries probably resulted in record flooding in the Greeley area. The current peak of record at a State of Colorado streamgage at Kersey, about $6.5 \mathrm{mi}$ downstream from Greeley, is 31,500 ft $3 / \mathrm{s}$ from 1973. For the September 2013 event, the USGS computed a peak flow of $60,000 \mathrm{ft}^{3} / \mathrm{s}$ at Fort Morgan, about $45 \mathrm{mi}$ downstream from Kersey. Given that there was minimal inflow between Kersey and Fort Morgan, the USGS estimates there was probably at least $60,000 \mathrm{ft}^{3} / \mathrm{s}$ at Kersey, which would be almost double the peak streamflow of record from 1973.

Flooding in the Fountain Creek Basin was primarily contained to Fountain Creek from southern Colorado Springs to its confluence with the Arkansas River in Pueblo, in lower Monument Creek, and in several mountain tributaries. All of the streamgages in the Fountain Creek Basin recorded streamflow peaks on September 12 or 13, 2013, coinciding with the period of maximum rainfall. Twelve streamgages with at least 10 years of record had peak streamflows during the September
2013 flood that ranked in the top five for the period of record, and 4 of those sites set a new record peak streamflow.

Flooding originated in the upper part of the Fountain Creek Basin coinciding with heavy rainfall that occurred in and around the Colorado Springs metropolitan area. Data from a network of USGS rain gages indicate that rainfall for September 10-16, 2013, generally increased from about 2 to 16 inches from east to west across Colorado Springs with the highest amounts occurring in the foothills south and southwest of the city.

Relatively small amounts of rainfall were not enough to produce flooding in the Sand Creek Basin in eastern Colorado Springs and most of the Monument Creek Basin. At many streamgages in these basins, streamflows were higher in August 2013 compared to September 2013. An exception was a streamflow peak of $6,150 \mathrm{ft}^{3} / \mathrm{s}$ ranking third highest in 11 years of record near the mouth of Monument Creek. New record peak streamflows were documented at two streamgages located on mountain tributaries on the west side of Colorado Springs (Bear and Cheyenne Creeks). Both these streamgages have 22 years of record. Five streamgages with at least 10 years of record in a 32-mile reach of Fountain Creek extending from Colorado Springs to Piñon had peak streamflows in the top five for the period of record.

New record peak streamflows were also recorded at two sites in the Little Fountain Creek Basin; Rock Creek above Fort Carson Reservation (35 years of record), and Little Fountain Creek near Fountain (12 years of record). Inflow from these two mountain tributaries contributed to a peak of $15,300 \mathrm{ft}^{3} / \mathrm{s}$ at the Fountain Creek near Fountain streamgage; the highest streamflow recorded in the Fountain Creek Basin during the September 2013 event and ranking the third highest in 46 years of record. Near the mouth of the Fountain Creek Basin in the City of Pueblo, streamflow in Fountain Creek peaked at 11,800 $\mathrm{ft}^{3} / \mathrm{s}$ and ranked only thirteenth highest out of 74 annual peaks with the highest on record being $47,000 \mathrm{ft}^{3} / \mathrm{s}$ in 1965 .

\section{References Cited}

Benson, M.A., and Dalrymple, T., 1967, General field and office procedures for indirect measurements: U.S. Geological Survey Techniques of Water-Resources Investigations, book 3, chap. A1, 30 p.

Bodhaine, G.L., 1968, Measurement of peak discharge at culverts by indirect methods: U.S. Geological Survey Techniques of Water-Resources Investigations, book 3, chap. A3, $48 \mathrm{p}$.

CH2MHILL, 2014, Boulder Creek hydrologic analysis: accessed September 12, 2014, at http://cwcbweblink.state.co.us/weblink/0/doc/192370/Electronic. aspx?searchid=ac0cf8f5-3535-4578-b294-f198b1ab4b6d. 
Collins, D.L., Doesken, N.J., and Stanton, W.P., 1991, Colorado floods and droughts: U.S. Geological Survey WaterSupply Paper 2375, p. 207-214.

Colorado Division of Water Resources, 2014a, Hydrography and satellite monitoring: accessed September 2, 2014, at http://water.state.co.us/SurfaceWater/HydrographySatMon/ Pages/default.aspx.

Colorado Division of Water Resources, 2014b, Colorado's surface water conditions: accessed September 5, 2014, at http://www.dwr.state.co.us/Surfacewater/data/division. $\operatorname{aspx}$ ?div $=1$.

Colorado Division of Homeland Security and Emergency Management, 2014, Review of 2013 Colorado floods: accessed September 12, 2014, at http://www.coemergency. $\mathrm{com} /$.

Colorado State University, 2007, University history 1997 flood: accessed August 17, 2014, at http://www.colostate. edu/features/flood97-main.aspx.

Dalrymple, Tate, and Benson, M.A., 1968, Measurement of peak discharge by the slope-area method: U.S. Geological Survey Techniques of Water-Resources Investigations, book 3, chap. A2, 12 p.

Dennehy, K.F., Litke, D.W., Tate, C.M., and Heiny, J.S., 1993, South Platte River Basin-Colorado, Nebraska, and Wyoming: Water Resources Bulletin, v. 28, no. 4, p. 647-683.

Federal Emergency Management Agency, 2014, Major Disaster Declaration DR-4145: accessed September 12, 2014, at https://www.fema.gov/disaster/4145.

Follansbee, Robert, and Sawyer, L.R., 1948, Floods in Colorado: U.S. Geological Survey Water-Supply Paper 997, $151 \mathrm{p}$.

Griffin, Steve, 2014, Peak flow hydrology investigation for the September 2013 flood at Interstate 25: Colorado Department of Transportation Region 4 Hydraulics Unit, 43 p.

Gotvald, A.J., 2010, Surface-water quality-assurance plan for the U.S. Geological Survey Georgia Water Science Center, 2010: U.S. Geological Survey Open-File Report 2010-1263, 43 p.

Hulsing, Harry, 1967, Measurement of peak discharge at dams by indirect methods: U.S. Geological Survey Techniques of Water-Resources Investigations, book 3, chap. A5, 29 p.

Houck, Kevin, 2014, Colorado Department of Transportation/ Colorado Water Conservation Board hydrology investigation, Phase one-2013 flood peak flow determinations: accessed September 2, 2014, at http://water.state.co.us/ DWRIPub/Documents/Phase \%20One \%20-\%202013\%20 Flood $\% 20$ Peak $\% 20$ Flow $\% 20$ Determinstions $\% 20$ with $\% 20$ Exhibits.pdf.
Jacobs Engineering Group, Inc., 2014a, Hydrologic evaluation of the Big Thompson watershed, post September 2013 flood event: accessed September 12, 2014, at http:// cwcbweblink.state.co.us/weblink/0/doc/192371/Electronic. aspx?searchid=ac0cf8f5-3535-4578-b294-f198b1ab4b6d.

Jacobs Engineering Group, Inc., 2014b, Hydrologic evaluation of the Lefthand Creek watershed, post September 2013 flood event: accessed September 12, 2014, at http:// cwcbweblink.state.co.us/weblink/0/doc/192372/Electronic. aspx? searchid=ac0cf8f5-3535-4578-b294-f198b1ab4b6d.

Jacobs Engineering Group, Inc., 2014c, Hydrologic evaluation of the St. Vrain watershed, post September 2013 flood event: accessed September 12, 2014, at http:// cwcbweblink.state.co.us/weblink/0/doc/192373/Electronic. aspx?searchid=ac0cf8f5-3535-4578-b294-f198b1ab4b6d.

Jarrett, R.D., and Costa, J.E., 2006, 1976 Big Thompson Flood, Colorado- Thirty years later: U.S. Geological Survey Fact Sheet 2006-3095, 6 p.

Kohn, M.S., Fulton, J.W., Williams, C.A., and Stogner, R.W., Sr., 2014, Remediation scenarios for attenuating peak flows and reducing sediment transport in Fountain Creek, Colorado, 2013: U.S. Geological Survey Scientific Investigations Report 2014-5019, 62 p.

Ley, T.W., DeArcos, P.L., Stroud, R.V., and Hutchens, D.G., 2010, The Colorado satellite-linked water resources monitoring system; 25 years later: accessed August 17, 2014, at http://water.state.co.us/DWRIPub/DWR\%20General\%20 Documents/USCIDColoradoSMSpaper_Ley.pdf.

Lukas, Jeff, 2013a, The September 2013 Front Range floods, 75 years later, weather history repeats itself: accessed September 17, 2014, at http://ciresblogs.colorado.edu/ flood/2013/09/23/75-years-later-weather-history-repeatsitself/.

Lukas, Jeff, 2013b, Severe Flooding on the Colorado Front Range September 2013: Preliminary assessment report from the Cooperative Institute for Research in Environmental Sciences Western Water Assessment at the University of Colorado, National Oceanic and Atmospheric Administration Earth System Research Laboratory, and Colorado State University Colorado Climate Center, 4 p., accessed March 21, 2014, at http://wwa.colorado.edu/resources/frontrange-floods/assessment.pdf.

Matthai, H.F., 1967, Measurement of peak discharge at width contractions by indirect methods: U.S. Geological Survey Techniques of Water-Resources Investigations, book 3, chap. A4, 44 p.

Matthai, H.F., 1969, Floods of June 1965 in South Platte River Basin, Colorado: U.S. Geological Survey Water-Supply Paper 1850-B, 64 p. 
McCain, J.F., and Shroba, R.R., 1979, Storm and flood of July 31-August 1, 1976, in the Big Thompson River and Cache la Poudre River basins, Larimer and Weld Counties, Colorado: U.S. Geological Survey Professional Paper $1115-\mathrm{A}, \mathrm{B}, 152 \mathrm{p}$.

McDonald, Richard, Nelson, J, Kinzel, P., and Conaway, J., 2006, Modeling surface-water flow and sediment mobility with the Multi-Dimensional Surface-Water Modeling System (MD_SWMS): U.S. Geological Survey Fact Sheet 2005-3078, 6 p.

National Climatic Data Center, 2015a, Data for station Fountain 0.5 E, CO US GHCND:US1COEP0169: accessed April 15, 2015, at http://www.ncdc.noaa.gov/cdo-web/datasets/GHCND/stations/GHCND:US1COEP0169/detail.

National Climatic Data Center, 2015b, Data for station Pueblo Memorial Airport, CO US GHCND:USW00093058: accessed April 15, 2015, at http://www.ncdc.noaa.gov/cdoweb/datasets/GHCND/stations/GHCND:USW00093058/ detail.

National Oceanic and Atmospheric Administration, 2013, Exceedance probability analysis for the Colorado Flood Event, 9-16 September 2013: accessed August 17, 2014, at http://www.nws.noaa.gov/oh/hdsc/aep_storm_analysis/8_ Colorado_2013.pdf.

National Oceanic and Atmospheric Administration, 2014a, The record Front Range and Eastern Colorado Floods of September 11-17, 2013: accessed October 3, 2014, at http:// www.nws.noaa.gov/om/assessments/pdfs/14 colorado_ floods.pdf.

National Oceanic and Atmospheric Administration, 2014b, Boulder monthly climate data-Precipitation: accessed October 3, 2014, at http://www.esrl.noaa.gov/psd/boulder/ Boulder.mm.precip.html.

Nelson, J.M., and McDonald, R.R., 1996, Mechanics and modeling of flow and bed evolution in lateral separation eddies: U.S. Geological Survey Grand Canyon Monitoring and Research Center, accessed September 1, 2015, at http:// www.gcmrc.gov/library/reports/GCES/Physical/hydrology/ Nelson1996.pdf.

Nelson, J.M., Bennett, J.P., and Wiele, S.M., 2003, Flow and sediment-transport modeling, in Kondolf, G.M., and Piegay, H., eds., Tools in fluvial geomorphology: England, Wiley, p. $539-576$.
Nelson, J.M., Shimizu, Y., Takebayashi, H., and McDonald, R.R., 2010, The International River Interface Cooperativepublic domain software for river modeling. Proceedings of the 2nd Joint Federal Interagency Conference on Sedimentation and Hydrologic Modeling, June 27-July 1, 2010, Las Vegas, Nevada, USA., accessed September 1, 2015, at http://acwi.gov/sos/pubs/2ndJFIC/Contents/3E_Nelson_03_01_10.pdf.

Snipes, R.J., and others, 1974, Floods of 1965 in Arkansas River Basin, Colorado, Kansas, and New Mexico: U.S. Geological Survey Water-Supply Paper 1850-D, 97 p.

Turnipseed, P.D., and Sauer, V.B., 2010, Discharge measurements at gaging stations: U.S. Geological Survey Techniques and Methods, book 3, chap. A8, 87 p.

Urban Drainage and Flood Control District, 2014a, Urban Drainage and Flood Control District's real-time data pages: accessed September 3, 2014, at https://udfcd.onerain.com/ home.php.

Urban Drainage and Flood Control District, 2014b, September 2013 flood peaks: accessed September 2, 2014, at http:// alert5.udfcd.org/wp/?p=205.

Urban Drainage and Flood Control District, 2014c, A September to remember, the 2013 Colorado Flood within the Urban Drainage and Flood Control District: Urban Drainage and Flood Control District, 208 p.

URS, 2014, Coal Creek-Headwaters to Jefferson/Boulder County line: accessed September 12, 2014, at http:// cwcbweblink.state.co.us/weblink/0/doc/192390/Electronic. aspx? searchid=8e8cfa49-d7a2-4a8d-bbde-a1f701c7afba.

U.S. Geological Survey, 2014, USGS water data for Colorado: U.S. Geological Survey National Water Information System, accessed August 7, 2014, at http://nwis.waterdata. usgs.gov/co/nwis.

Western Regional Climate Center, 2014, Remote Automatic Weather Stations (RAWS) USA Climate Archive: accessed September 3, 2014, at http://www.raws.dri.edu/index.html.

Yochum, S.E., and Moore, D.S., 2013, Colorado Front Range Flood of 2013 - Peak flow estimates at selected mountain stream locations: U.S. Department of Agriculture, Natural Resources Conservation Service, Colorado State Office, 38 p., accessed September 2, 2014, at http://water. state.co.us/DWRIPub/Documents/PeakFlowEstimates NRCS_12-16-2013[1]\%20(1).pdf.

Zuellig, R.E., Bruce, J.F., Evans, E.E., and Stogner, R.W., 2008, Urban-related environmental variables and their relation with patterns in biological community structure in the Fountain Creek Basin, Colorado, 2003-2005: U.S. Geological Survey Scientific Investigations Report 2007-5225, $24 \mathrm{p}$. 
Appendixes 


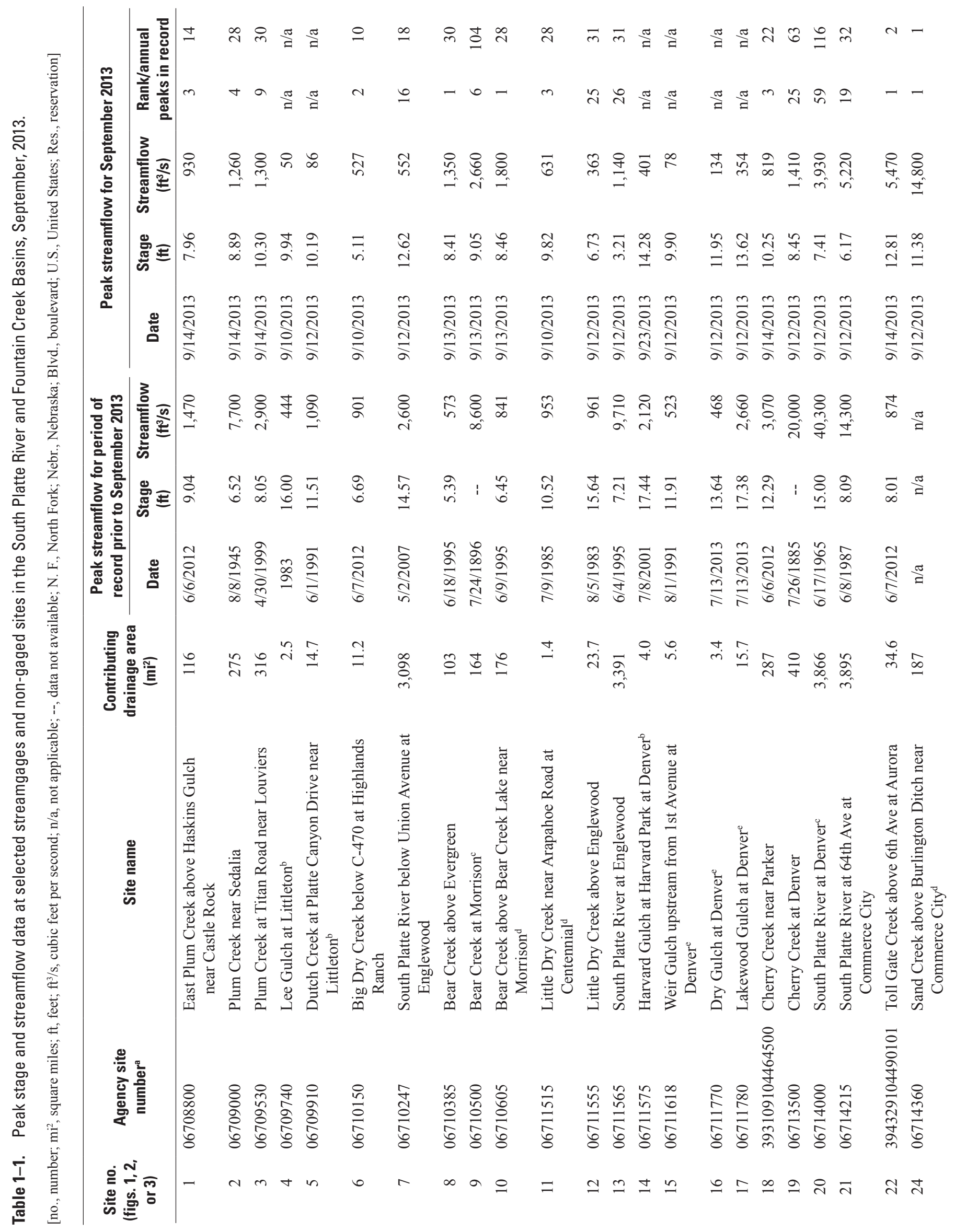




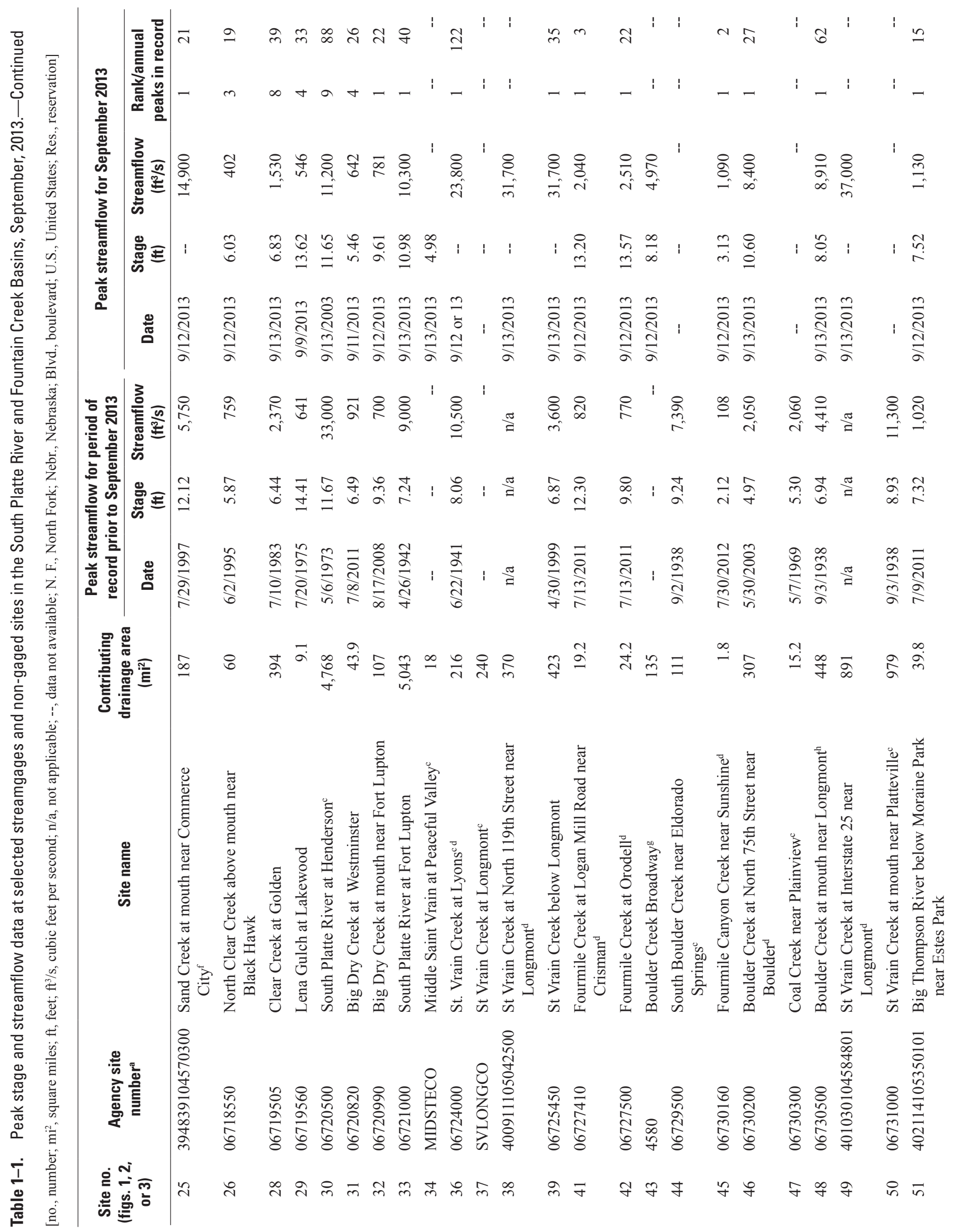




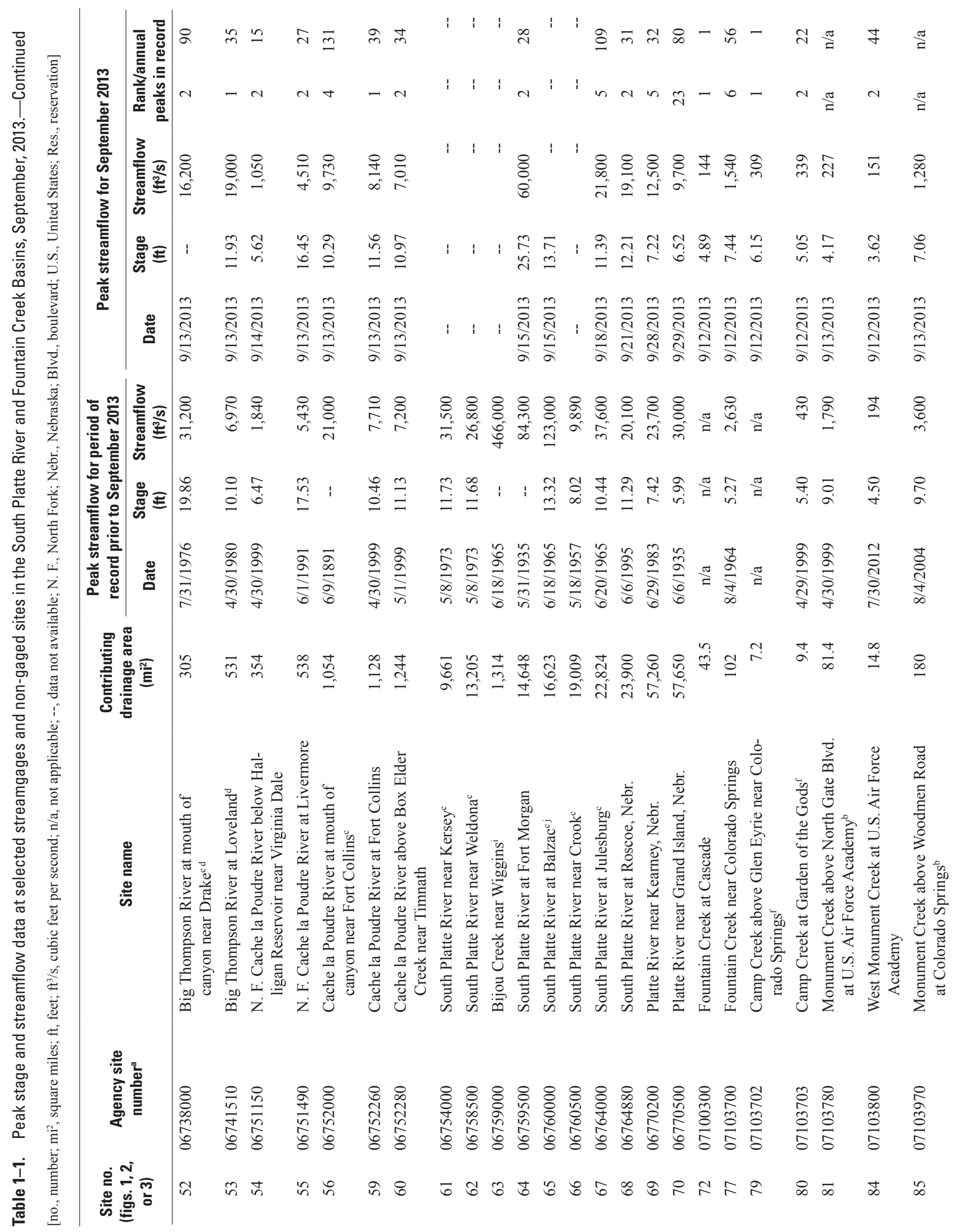




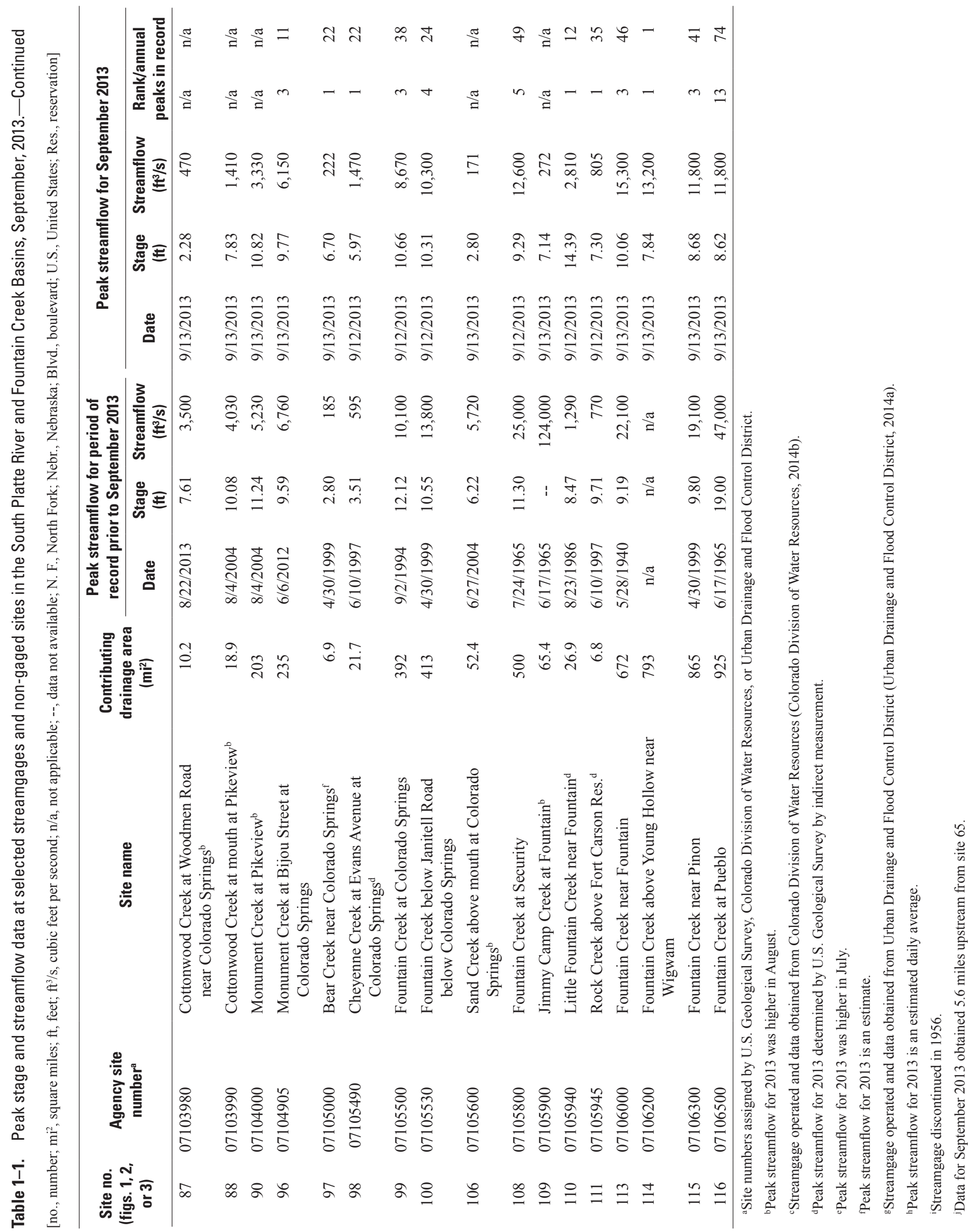


Table 1-2. Rainfall data for selected sites in the South Platte River and Fountain Creek Basins, September, 2013.

[no., number; NWS, National Weather Service; ID, identificaton; --, not applicable; SE, southeast; NW, northwest; Sec., section; T, township; N, north; R, range; W, west; WWTP, wastewater treatment plant; U.S., United States; N., north; Blvd., boulevard; E., east]

\begin{tabular}{|c|c|c|c|c|}
\hline $\begin{array}{l}\text { Site no. } \\
\text { (figs. } 2,3 \text {, } \\
\text { or } 17 \text { ) }\end{array}$ & $\begin{array}{l}\text { Agency } \\
\text { site number }\end{array}$ & Site name & Period of rainfall reported & $\begin{array}{c}\text { Total } \\
\text { rainfall } \\
\text { (inches) }\end{array}$ \\
\hline 23 & 700 & Toll Gate at 6 th $^{\mathrm{b}}$ & 9/9/2013 11:57 p.m.-9/16/2013 11:57 p.m. & 12.52 \\
\hline 27 & NWS ID 52003 & Lookout Mountain Colorado ${ }^{c}$ & 9/9/2013 1:00 a.m.-9/15/2013 11:59 p.m. & 9.64 \\
\hline 35 & 4310 & Johnny Park ${ }^{\mathrm{b}}$ & 9/9/2013 2:41 a.m.-9/15/2013 9:27 p.m. & 12.29 \\
\hline 40 & NWS ID 50604 & Sugar Loaf Colorado ${ }^{c}$ & 9/9/2013 1:00 a.m.-9/15/2013 11:59 p.m. & 12.95 \\
\hline 58 & -- & $\begin{array}{l}\text { SE1/4 NW1/4 Sec. } 31, \text { T.8N., R.70W., } \\
\text { Larimer County }^{\mathrm{d}}\end{array}$ & $7 / 31 / 1976-8 / 2 / 1976$ & 10.24 \\
\hline 71 & 385653104583101 & Sand Gulch met station above Chipita Park & 9/10/2013 12:05 a.m.-9/16/2013 11:55 p.m. & 5.63 \\
\hline 72 & 07100300 & Fountain Creek at Cascade & 9/10/2013 12:05 a.m.-9/16/2013 11:55 p.m. & 5.38 \\
\hline 75 & 385334104544901 & $\begin{array}{l}\text { Upper Williams Canyon met above Manitou } \\
\text { Springs }\end{array}$ & 9/10/2013 12:05 a.m.-9/16/2013 11:55 p.m. & 10.00 \\
\hline 76 & 385129104544601 & $\begin{array}{l}\text { Manitou Springs met below Ruxton Creek } \\
\text { at Manitou Springs }\end{array}$ & 9/10/2013 12:05 a.m.-9/16/2013 11:55 p.m. & 9.10 \\
\hline 78 & 385640104555701 & $\begin{array}{l}\text { Upper Queens Canyon met station near } \\
\text { Ormes Peak }\end{array}$ & 9/10/2013 12:05 a.m.-9/16/2013 11:55 p.m. & 8.35 \\
\hline 79 & 07103702 & $\begin{array}{l}\text { Camp Creek above Glen Eyrie near } \\
\text { Colorado Springs }\end{array}$ & 9/10/2013 12:05 a.m.-9/16/2013 11:55 p.m. & 8.64 \\
\hline 80 & 07103703 & Camp Creek at Garden of the Gods & 9/10/2013 12:05 a.m.-9/16/2013 11:55 p.m. & 9.23 \\
\hline 82 & 385906104495101 & $\begin{array}{l}\text { WWTP meteorological station at } \\
\text { U.S. Air Force Academy }\end{array}$ & 9/10/2013 12:05 a.m.-9/16/2013 11:55 p.m. & 8.70 \\
\hline 86 & 385636104465601 & $\begin{array}{l}\text { N. Academy met station near Briargate Blvd. } \\
\text { at Colorado Springs }\end{array}$ & 9/10/2013 12:05 a.m.-9/16/2013 11:55 p.m. & 5.55 \\
\hline 87 & 07103980 & $\begin{array}{l}\text { Cottonwood Creek at Woodmen Road near } \\
\text { Colorado Springs }\end{array}$ & 9/10/2013 12:05 a.m.-9/16/2013 11:55 p.m. & 4.76 \\
\hline 89 & 385548104503201 & $\begin{array}{l}\text { Foothills met station at Foothills Elementary } \\
\text { at Colorado Springs }\end{array}$ & 9/10/2013 12:05 a.m.-9/16/2013 11:55 p.m. & 5.79 \\
\hline 91 & 385520104530401 & $\begin{array}{l}\text { Douglas Creek met above Flying West Ranch } \\
\text { Road at Colorado Springs }\end{array}$ & 9/10/2013 12:05 a.m.-9/16/2013 11:55 p.m. & 8.31 \\
\hline 92 & 385349104501401 & $\begin{array}{l}\text { Douglas Creek met above North Chestnut } \\
\text { Street at Colorado Springs }\end{array}$ & 9/10/2013 12:05 a.m.-9/16/2013 11:55 p.m. & 5.71 \\
\hline 93 & 385351104454601 & $\begin{array}{l}\text { Templeton Gap met above Austin Bluffs at } \\
\text { Colorado Springs }\end{array}$ & 9/10/2013 12:05 a.m.-9/16/2013 11:55 p.m. & 5.67 \\
\hline 94 & 385240104444801 & $\begin{array}{l}\text { Penrose met at Penrose Elementary at } \\
\text { Colorado Springs }\end{array}$ & 9/10/2013 12:05 a.m.-9/16/2013 11:55 p.m. & 5.08 \\
\hline
\end{tabular}


Table 1-2. Rainfall data for selected sites in the South Platte River and Fountain Creek Basins, September, 2013.—Continued

[no., number; NWS, National Weather Service; ID, identificaton; --, not applicable; SE, southeast; NW, northwest; Sec., section; T, township; N, north; R, range; W, west; WWTP, wastewater treatment plant; U.S., United States; N., north; Blvd., boulevard; E., east]

\begin{tabular}{|c|c|c|c|c|c|}
\hline $\begin{array}{l}\text { Site no. } \\
\text { (figs. } 2,3 \text {, } \\
\text { or } 17 \text { ) }\end{array}$ & $\begin{array}{l}\text { Agency } \\
\text { site number }\end{array}$ & Site name & & Period of rainfall reported & $\begin{array}{c}\text { Total } \\
\text { rainfall } \\
\text { (inches) }\end{array}$ \\
\hline 95 & 385121104480701 & $\begin{array}{l}\text { Shooks Run met at Patty Jewett Golf Course } \\
\text { at Colorado Springs }\end{array}$ & $9 / 10 / 2013$ & 12:05 a.m.-9/16/2013 11:55 p.m. & 7.64 \\
\hline 96 & 07104905 & $\begin{array}{l}\text { Monument Creek at Bijou Street at } \\
\text { Colorado Springs }\end{array}$ & $9 / 10 / 2013$ & 12:05 a.m.-9/16/2013 11:55 p.m. & 8.69 \\
\hline 98 & 07105490 & $\begin{array}{l}\text { Cheyenne Creek at Evans Avenue at } \\
\text { Colorado Springs }\end{array}$ & $9 / 10 / 2013$ & 12:05 a.m.-9/16/2013 11:55 p.m. & 13.59 \\
\hline 101 & 385740104405501 & $\begin{array}{l}\text { Upper Sand Creek met above Lochwinnoch } \\
\text { Lane at Colorado Springs }\end{array}$ & $9 / 10 / 2013$ & 12:05 a.m.-9/16/2013 11:55 p.m. & 3.15 \\
\hline 102 & 385519104415501 & $\begin{array}{l}\text { Ridgeview met below Dublin Blvd. at } \\
\text { Colorado Springs }\end{array}$ & $9 / 10 / 2013$ & 12:05 a.m.-9/16/2013 11:55 p.m. & 3.43 \\
\hline 105 & 384908104453301 & $\begin{array}{l}\text { South Academy Blvd. meteorologic station } \\
\text { at Colorado Springs }\end{array}$ & $9 / 10 / 2013$ & 12:05 a.m.-9/16/2013 11:55 p.m. & 5.86 \\
\hline 107 & 384537104494701 & $\begin{array}{l}\text { Oak Meadow Park meteorologic station at } \\
\text { Colorado Springs }\end{array}$ & $9 / 10 / 2013$ & 12:05 a.m.-9/16/2013 11:55 p.m. & 11.49 \\
\hline 108 & 07105800 & Fountain Creek at Security & $9 / 10 / 2013$ & 12:05 a.m.-9/16/2013 11:55 p.m. & 2.94 \\
\hline 112 & 384053104492001 & $\begin{array}{l}\text { Rod and Gun meteorologic station at Fort } \\
\text { Carson }\end{array}$ & $9 / 10 / 2013$ & 12:05 a.m.-9/16/2013 11:55 p.m. & 15.64 \\
\hline
\end{tabular}

${ }^{a}$ Site numbers assigned by the U.S. Geological Survey or Urban Drainage and Flood Control District, or obtained from the Western Region Climate Center (2014).

bata obtained from the Urban Drainage and Flood Control District (2014a).

'Data obtained from the Western Region Climate Center (2014).

${ }^{\mathrm{D}}$ Data obtained from McCain and Shroba (1979, p. 49). 
Publishing support provided by: Rolla Publishing Service Center

For more information concerning this publication, contact: Chief, USGS Office of Surface Water

415 National Center

12201 Sunrise Valley Drive

Reston, VA 20192

(703) 648-5301

Or visit the Office of Surface Water Web site at: http://water.usgs.gov/osw/ 

